Portland State University

PDXScholar

3-4-1976

\title{
The Effect of a Magnetic Field on the Leclanché Cell
}

Walter Edward Socha

Portland State University

Follow this and additional works at: https://pdxscholar.library.pdx.edu/open_access_etds

Part of the Physics Commons

Let us know how access to this document benefits you.

\section{Recommended Citation}

Socha, Walter Edward, "The Effect of a Magnetic Field on the Leclanché Cell" (1976). Dissertations and Theses. Paper 2561.

https://doi.org/10.15760/etd.2558

This Thesis is brought to you for free and open access. It has been accepted for inclusion in Dissertations and Theses by an authorized administrator of PDXScholar. Please contact us if we can make this document more accessible: pdxscholar@pdx.edu. 
AN ABSTRACT OF THE THESIS OF Walter Edward Socha for the Master of Science in Physics presented Narch 4. 1976

Title: The Effect of an Applied Magnetic Field on the Leclanche Cell AFPROVED BY MEMBERS OF THE THESIS COMITTEE:
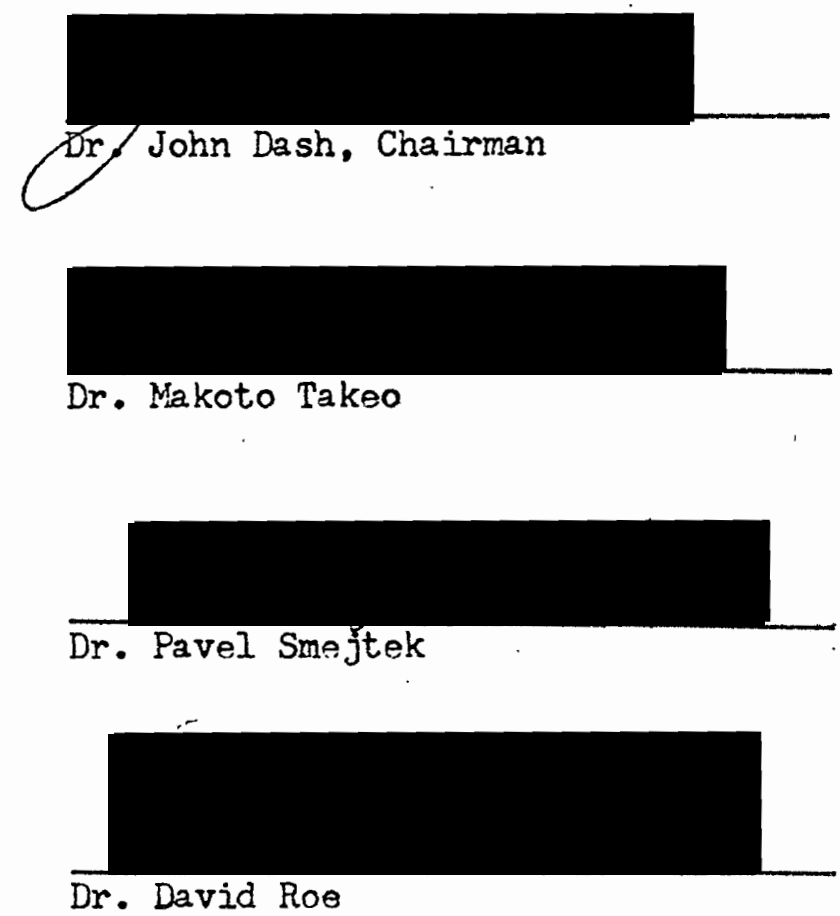

The effect of a magretic field on an electrochemical system, the Leclanché cell, was investigated. Experiments show that there is an increase in power output and charge passed when a cell is discharged in an applied magnetic field.

Possible explanations for the effect and discriptions of attempts to verify these explanations are presented. 
THE EFFECT OF A MAGNETIC FIELD

ON THE LECLANCHÉ CELL

by

WAITER EDWARD SOCHA

A thesis submitted in partial fulfillment of the requirements for the degree of

MASTER OF SCIENCE

in

PHYSICS.

Portland State University

1976 
TO THE OFFICE OF GRADUATE STUDIES AND RESEARCH

The members of the committee approve the thesis of

Walter Edward Socha presented March 4*. 1976
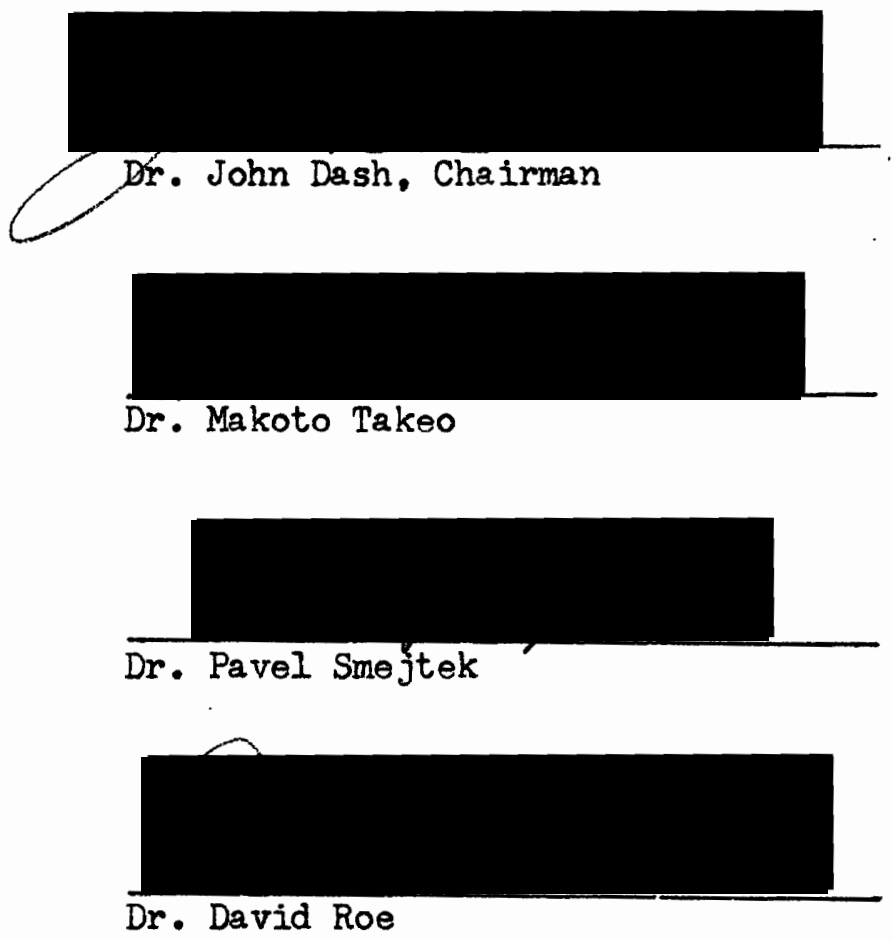

APPROVED:

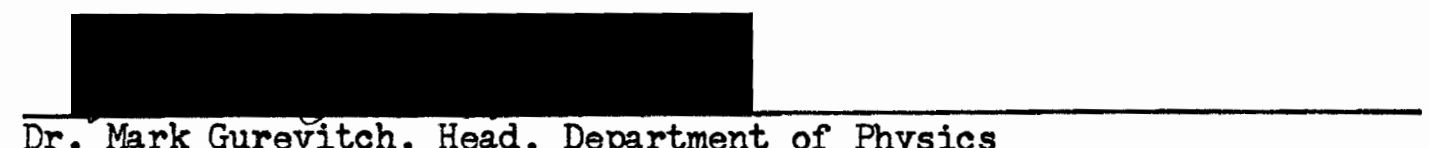

Dr. Mark Gurevitch, Head, Department of Physics

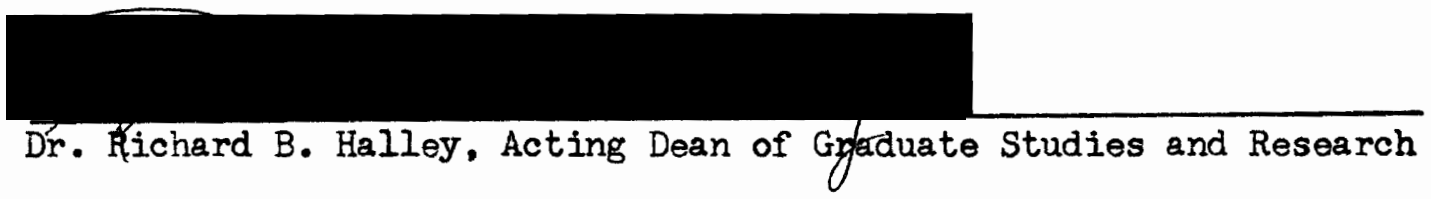




\section{ACKNONLEDGNENT}

I wish to thank Dr. John Dash, without whose help, suggestions, and patience, this thesis would not be written. 
TABLE OF CONTENTS

PAGE

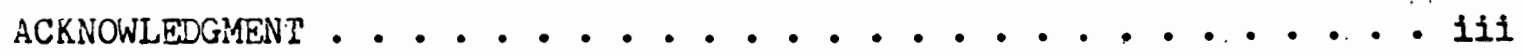

IIST OF TABLES .................. vi

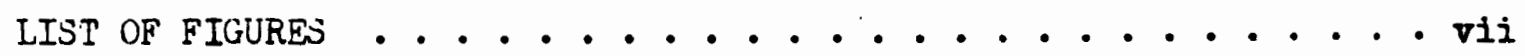

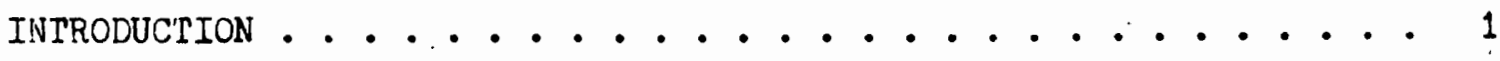

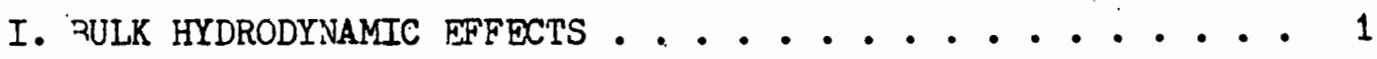

II. INHIBITION OF HYDROGEN EVOLUTION ........... 2

III. SOLUTION-METAL INTERFACE PHENOMENA. . . . . . . . 3

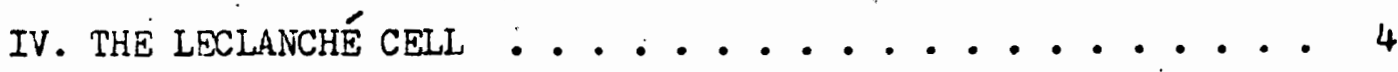

CEIL DISCHARGE EXPERIMENTS ................... 8

I. EXPERIMENTAL .................. 8

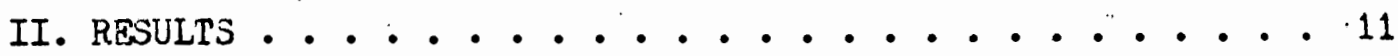

FURTHER INVGSTIGATIONS OF THE LECLANCHE CELL .......... 23

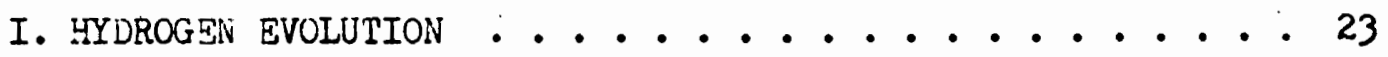

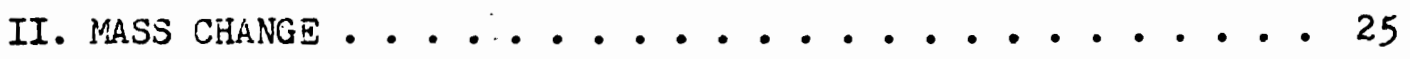

III. EXTEIT OF CORROSION . . . . . . . . . . . . 26

INVESTIGATIONS OF THE CORROSION OF ZINC . . . . . . . 28

I. CORROSION EXPERTMENTS .................... 28

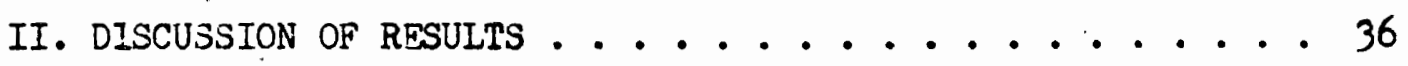

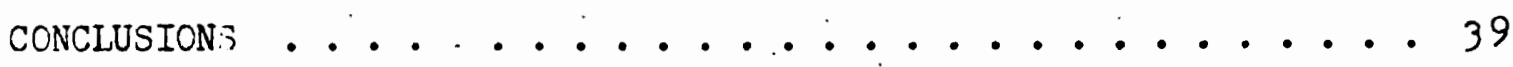

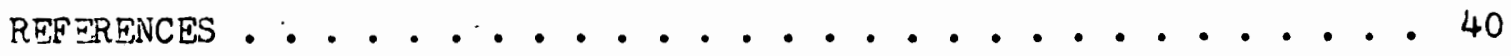

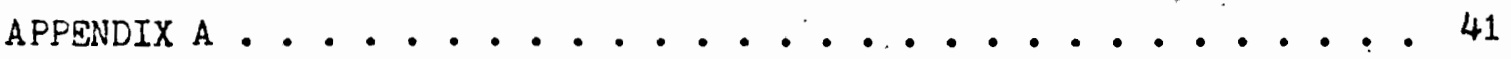

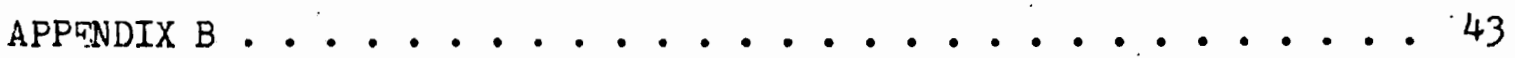




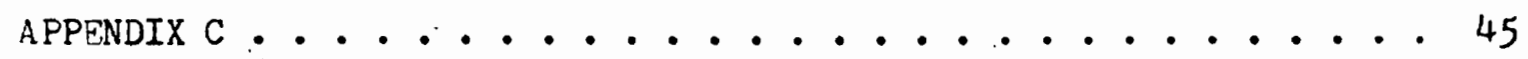

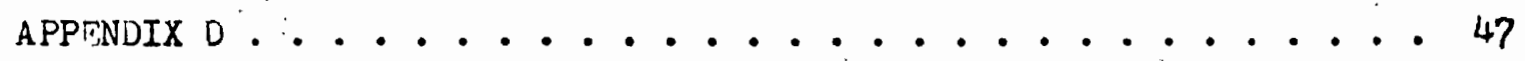
APPENDIX E . . . . . . . . . . . . . . . . . . . 52 APPENDIX F . . . . . . . . . . . . . . . . . . . 55 


\section{LIST OF TABLES}

TABLE

PAGE

I RESULIS UF CELL DISCHARGE EXPERIMENTS . . . . . . . . . 12

II DATA COMPUTED FOF EXEERIMENTS 5 THROUGH $9 . \cdots \cdot \ldots$

III. VOLTHGES ACROSS EACH SET OF CELLS IN EXPERIMENT 8 BEFORE AND AFTER A 534 MINUTE INTERRUPTION . . . . . . . . . . 18

IV EINERGY OUTPUT AND CHARGE PASSED FOR SIZE. N AND SIZE D CFIIS SUMMED OVER ALL EXPERIMENTS . . . . . . . . . 21

V MASS CHANGE OF SIZE D CELIS (BURGESS 210) DURING DISCHARGE AT $0^{\circ} \mathrm{C}$.................. 25

VI OPEN AREA OF LECLANCHÉ CELI CANS CORRODED DLE TO DISCHARGE . 27

VII MASS CHANGE OF THE ZINC SPECIMENS DUE TO CORROSION . . . . 30

VIII INDIVIDUAL DATA FOR ZINC CANS IN EXPERIMUNT C . . . . . 34 


\section{IIST OF FIGURES}

FIGURE

FAGE

1 Pictorial diagram of electrothinning of zinc and the relationship between the concentration of $\mathrm{Zn}^{++}(n)$

and the distance from the electrode $(x) . . . . . . . .11$

2 Pictorial diagram showing. the effective path (dotted

line.) of the ion under the influence of a magnetic field . 3

3 Yodorn leclanché cell (6) . . . . . . . . . . 5

4. Simplified illustration of corrosion ........... 7

5 Schomatic electrical circuit for cell discharge experiments ...................... 9

6 Cell alignment in the applied magnetic field ...... . 9

7 Schematic circuit of Experiment 9 . . . . . . . . 10

8 Tine effect of a magnetic field on the amount of charge passed by Leclanché cells ............. 14

9 The effect of a magnetic field on the energy output of Leclanché cells ................ 15

10 Graph of charge passed per cell versus the resistance load per cell for Experiments 5, 6, 7, 8, and 9....... 16

11 Graph of the energy output per cell versus the resistance load per cell for Experiments 5,6,7,8, and $9 . \ldots 17$

12 Rough plot of voltage versus elansed time for Experiment 919

13 Basic approaches to the detaction of hydrogen evolution: 24

14 Equipment and positioning of Experiment A . . . . . . 29

15 Fquipment and position of magnetic field in Experiment B - 32

16 Fosition of apparatus in Experiment $\mathrm{C} \ldots . . . . . .33$

17. Interior surface of zinc cans at end of Experimont c . . 35

18 Scinematic picture of differential aeration . . . . . . 37 
19 Possible explanation for the liquid-air Iine on the interior surface of the zinc cans used in Experiment $\mathrm{C} . \quad 38$ 


\section{INTRODUCTION}

\section{BULK HYDRODYNAMIC EFFECTS}

A. report by Dash and King (1) in 1972 shows that the electrochomical deposition and thinning of metals at constant current is more uniform if parformed in a manetic field. Also shown is that the resistance of an electrochemical cell may be reduced in a magnetic fleld.

This latter effect may be caused by the reduced thickness of the interface layer between the electrode and the bulk electrolyte: Fick's law states that the net drift $J$; expressed in carriers crossing a unit area per unit time is proportional to the concentration gradient.

$$
J=-D(d n / d x)
$$

whore $n$ is the number of molecules per unit vol. and $x$ is the distance in the direction of drift (see Figure 1). The proportionslity constant $D$ is known as the diffusion constant and is proportional to the mobility of the carriers (2).
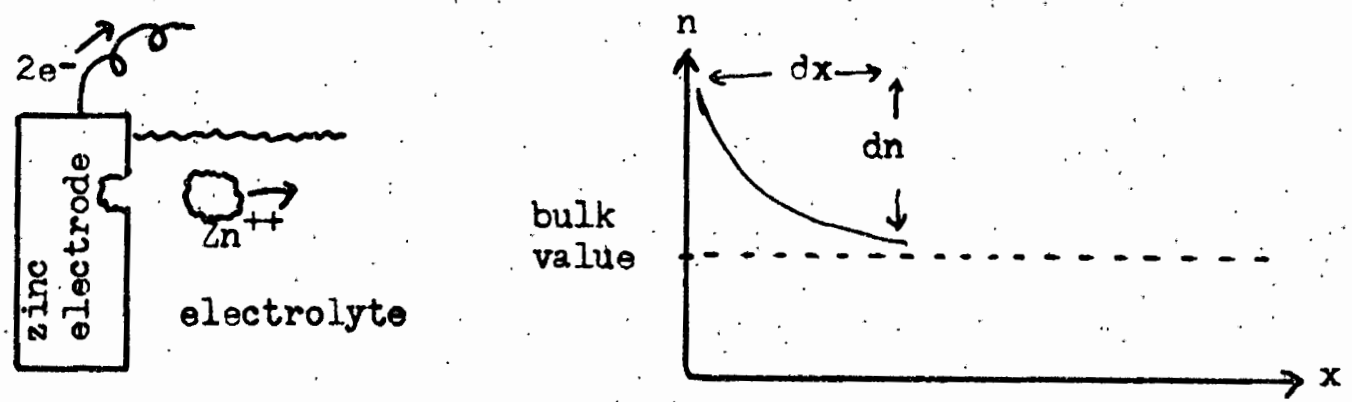

Figure 1. Pictorial diagram of electrothinning of $z$ inc and the relationship between the concentration of $2 n^{++}(n)$ and the: distance from the lectrode $(x), d n$ and $d x$ are infinitesimals. 
If at a constant current one obtains a lowering of impedance. then this may. be due to a steeper concentration gradient. Also, this observation may be due to a mixing effect.

In electrochemical cells, the current is carried by moving ions. Therefore, on observing a mixing effect in a magnetic field, the assumption must be that the Lorentz force $q(B \times v)$ is stirring the ions as they move. Drift vel. of the hydrogen ion is given as $22.5 \times 10^{-4} \mathrm{~cm} / \mathrm{sec}$ in a field of $1 \mathrm{volt} / \mathrm{cm}$ at $0^{\circ} \mathrm{C}$ (3). Using this value for the velocity in the Lorentz force and a value of 1 kilogauss ( $k G$ ) for the magnetic field strength normal to the velocity, one gets a value of $36 \times 10^{-26}$ newtons for the force deflecting the ion. Using $m=1.69 \times 10^{-2}$ ? kilograms for the mass of the ion, a further simplistic calculation yields an acceleration of $a=F / m=214$ meters $/ \mathrm{sec}^{2}$ perpendicular to the direction of motion. Note that the mobility was used for the velocity of the individual ion and no consideration was made for the mechanism of ionic conduction. However, even though arrived at with a naive calculation, the values of the force and acceleration of the ions are significant.

\section{INHIBITION OF HYDROGEN EVOLUTION}

Experiments performed by Tung in 1972 (4), and continued by Chen and Housen in 1975 (5), showed that the current efficiency for the deposition of chromium is greater when performed in an applied magnetic field. This means that a greater amount of chromium is deposited for the same amount of charge passed.

However, chromium co-deposites with hydrogen and Chen (5) found that a magnetic field inhibits hydrogen evolution. This inhibition of 
hydrogen evolution could be causod by 2 decrease in mobility of the hydrogen ion due to a HalI effect in the electrolyte. The investigation by D. Laforgue-Kanzter (3) of the Hall ef foct in aqueous electrolytes supports the thoory that the conductivity of aqueous solutions is partially due to the $\mathrm{H}_{3} \mathrm{O}^{+}$ion and partially due to a dry proton, the latter having an axtremely high mobility. A magnetic field could have a large effect on the movement of such a proton, reducing the mobility in the direction of the el-ctrode (see Figure 2).

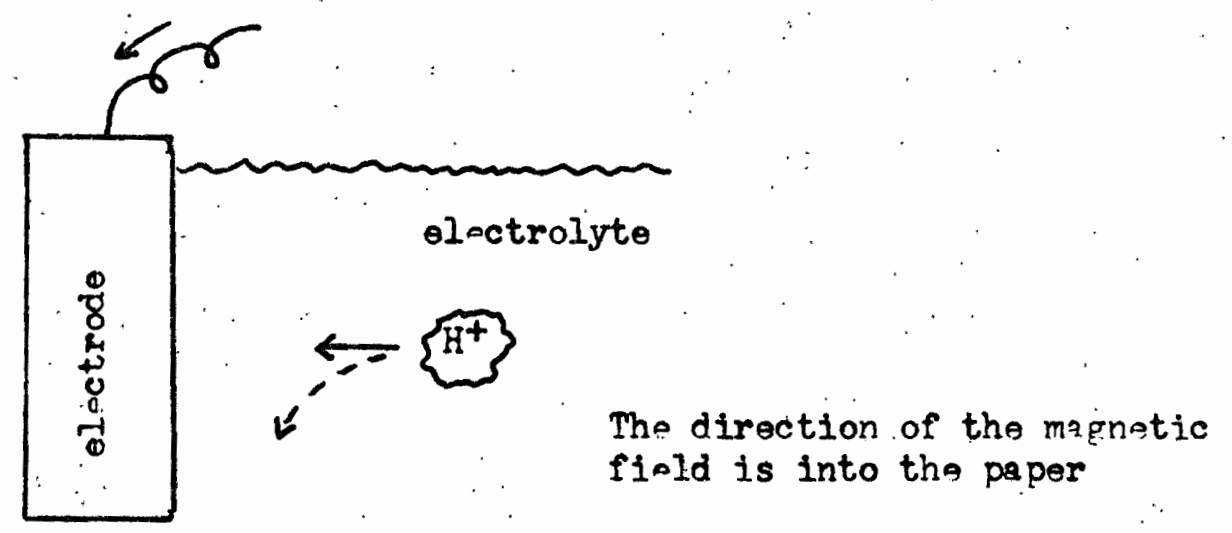

Figure 2. Pictorial diagram showing the effective path (dotted line) of the ion under the influence of a magnetic field.

$$
\text { III. SOLUTIONMETAL INTERFACE PHENOMENA }
$$

Other possible interactions of a magnetic field with an electrochemical coll may take place at the sol'n -metal interface. One possible offect is a change in the activation overpotential. This overpotential is the difference between the decomposition potential of the cell and the reversible potential (the potential at which the forward and reverse rates at the electrode are equal). It is connected with the shift in the Fermi level in the metal electrode from the value which it 
had when the electrode reactions were taking place' at an equal speed. It is possible to change the Fermi level of the electrons in the metal by the use of an applied magnetic field. The magnitude of this change 1s, here, the product of the Bohr magneton $\left(0.927 \times 10^{-20}\right.$ ergs/gauss) and the magnetic field strength. A field of $1 \mathrm{kG}$ would then change the Fermi level by approximately $10^{-17}$ orgs.

Improved understanding of the magnetic interaction with electrolysis would then result from the elimination of one of the folloring:

1. bulk hydrodynamic effects (mixing)

2. inhibition of hydrogen evolution

3. sol'n'-metal interface phenomena.

An electrochemical system with the electrolyte immobilized in the form of a paste or suspended in a fiberous material would decrease or - Iiminate the bulk mixing effect. For this reeson, an investigation of the operation of the Leclanché cell in a magnetic field was started.

\section{THE LECLANCHÉ CEL (6)}

The structure of a typical Leclanché cell is shown. In Figure 3. The basic cell consists of tho zinc can, separator, cathode mix, and carbon rod, with the electrolyte impregnating the cathode mix and separator.

The zinc can serves as the anode and to contain the cell. It is made by impset extrusion and a typical alloy consists of $1.0 \%$ lead, $0.05 \%$ cadmium, and the reviainder zinc of $99.99 \%$ purity. The alloying elements improve the mechanical properties and decrease wasteful corrosion. 


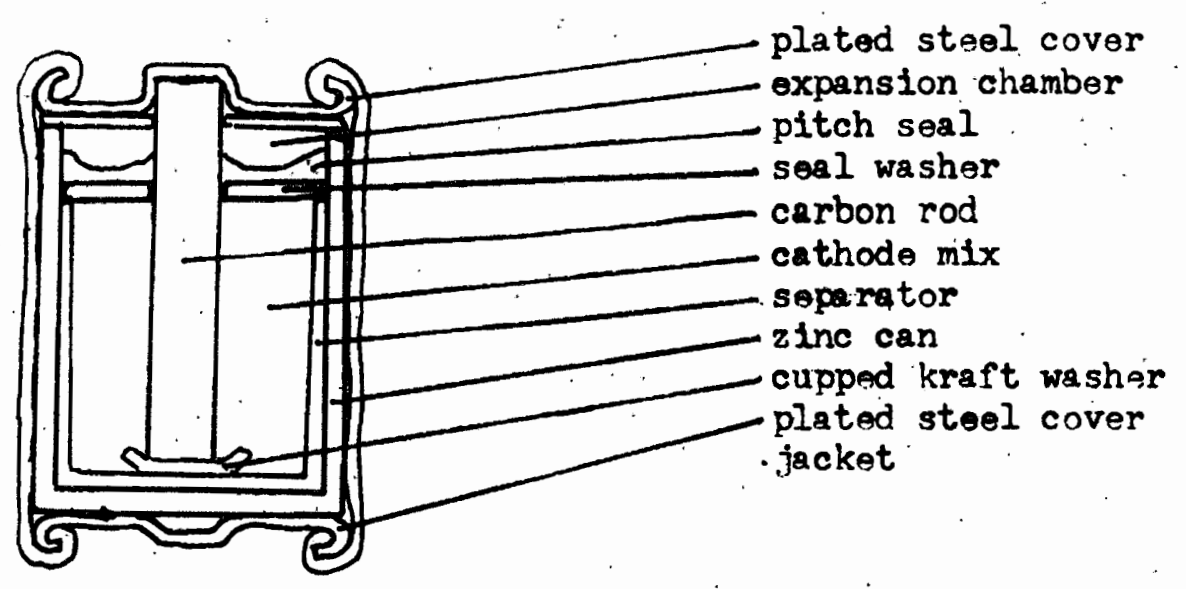

Fioure 3. Modern Leclanché coll (6).

The cathode mix consists of an uniform mixture of manganese dioxide $(=120 \mu)$, the actual cathode material, and carbon black (usually acetylene black).: The latter serves the double purpose of increasing tha conductivity of the $\mathrm{MnO}_{2}$ and absorbing the electrolyte. The ratio of $\mathrm{MnO}_{2}$ to carbon black may vary from 10:1 (transistor use) to $1: 1$ (ohotoflash batteries). The cathode mix also contains electrolyte amounting to about $25 \%$ of its total weight.

Tha electrolyte is made by dissolving ammonium chloride, zine chloride, and a small amount of mercuric chloride in water. This latter converts to zinc chloride as the mercury plates out on the zinc on contact. In use, the $\mathrm{pH}$ of the paste (electrolyte and cathode mix) near the zinc may vary from roughly 6 to 4, while for the innermost portions of tho mix, it may vary from 6. to 10.

The carbon rod serves as the conductor of electricity for the manganese dioxide electrode and also serves as a vent to allow hydrogen gas, which forms at the anode, to escape.

The sopanation of the two electrodes is accomplished by using 
kraft paper (a strong paper made from sulfato pulp) coated on the zine side with methyl cellulose containing mercurous(ic) chloride. The mercury coates the zinc (as with the mercury from the electrolyte) and inhibits its corrosion.

The basic anode reaction of the Leclanché cell is the oxidation of zine,

$$
\mathrm{Zn}=\mathrm{Zn}^{++}+2 \theta^{-}
$$

whilo the cathode reaction is the reduction of manganese dioxide,

$$
2 \mathrm{MnO}_{2}+2 \mathrm{H}^{+}+2 \mathrm{e}^{-}=\mathrm{Mn}_{2} \mathrm{O}_{3}+\mathrm{H}_{2} \mathrm{O}
$$

The standard reduction half-reactions and thermodynamic data for zinc and manganese dioxide are ( 7$) \ldots$

$$
\begin{array}{crl}
\mathrm{Zn}^{++}+2 \mathrm{e}^{-} \rightarrow \mathrm{Zn} & \begin{aligned}
\Delta \mathrm{G}^{\circ} & =+35.20 \mathrm{kcal} \\
\mathrm{E}^{\circ} & =-0.763 \text { volts }
\end{aligned} \\
\mathrm{MnO}_{2}+4 \mathrm{H}^{+}+2 \mathrm{e}^{-} \rightarrow \mathrm{Mn}^{++}+2 \mathrm{H}_{2} \mathrm{O} & \begin{aligned}
\Delta \mathrm{G}^{\circ} & =-55.733 \mathrm{kcal} \\
\mathrm{E}^{\circ} & =+1.208 \text { volts }
\end{aligned}
\end{array}
$$

The complete reduction of the $\mathrm{MnO}_{2}$ is complicated and occurs in a series of steps. The $\mathrm{Mn}_{2} \mathrm{O}_{3}$ is first formed, then MnOOH, and finally $\mathrm{Mn}_{3} \mathrm{O}_{4}$ (8). The removal of the $\mathrm{MnOOH}$ is considered to be the rate determining step of the overall raction (9). In acidic solutions, the removal is effected by

$$
2 \mathrm{MnOOH}+2 \mathrm{H}^{+}=\mathrm{MnO}_{2}+\mathrm{Mn}^{++}+2 \mathrm{H}_{2} \mathrm{O}
$$

For neutral and alkaline solutions, protons and electrons diffuse into the interior of the $\mathrm{MnO}_{2}$ particles, effectively removing the $\mathrm{MnOOH}$. At pH 3 to 6, both processes occur. In either case, formation and the removal of $\mathrm{MnOOH}$ is itself limited by the diffusion of protons. Corrosion at the zine anode (ses Figure 4) in the Ieclanché cell is an important factor in its performance. Corrosion requires two 
ractions, a reduction and an oxidation. The oxidation or anode reaction is zine dissolution,

$$
\mathrm{Zn}=2 \mathrm{n}^{++}+2 \mathrm{e}^{-}
$$

One possible reduction, which occurs at cathodic sites on the zinc anode, is that of hydrogen formation,

$$
2 \mathrm{H}^{+}+2 \mathrm{e}^{-}=\mathrm{H}_{2} \text {. }
$$

This necessitates venting, which allows a second reduction reaction, that of oxygen, which may occur anywhere in the cell.

$$
\mathrm{O}_{2}+4 \mathrm{H}^{+}+4 \mathrm{e}^{-}=2 \mathrm{H}_{2} \mathrm{O}
$$

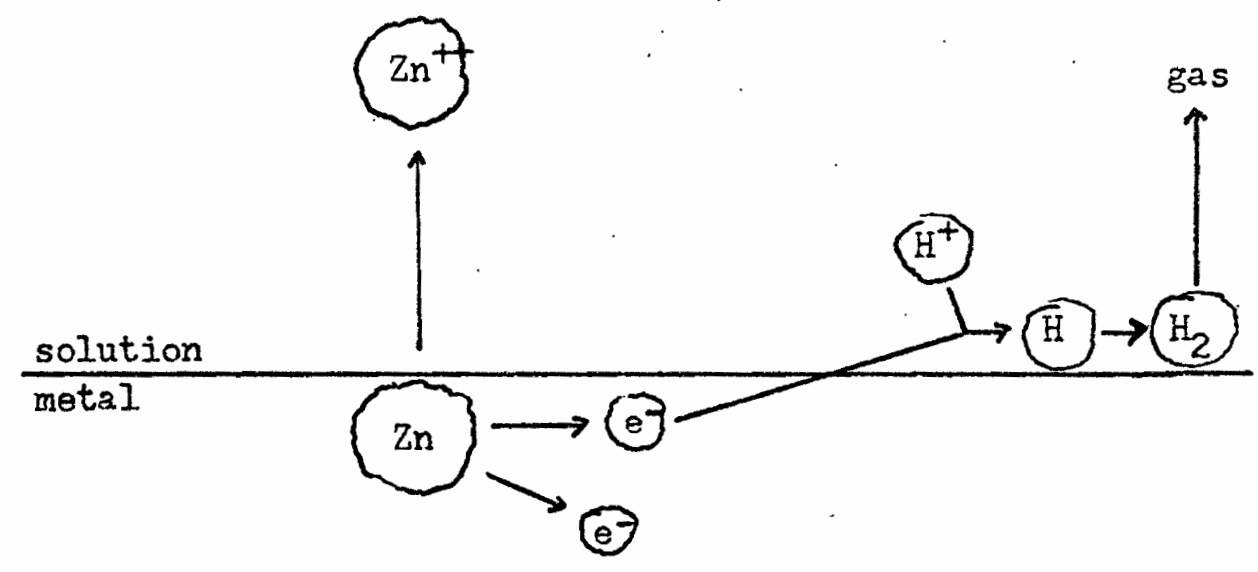

Figure 4. Simplified illustration of corrosion. The oxidation of zinc frees two electrons which combine with hydrogen ions to form atomic hydrogen. The atomic hydrogen then recombine into molecular $\mathrm{H}_{2}$. 


\section{CELI DISCHARGE EXPERIMENTS}

The investigation of the effects of a magnetic field on the

Leclanché cell was begun by measuring the energy output and charge passed by cells discharged with and without an applied field.

\section{EXPERIMENTAI}

Leclanché cells of size $N$ or $D$, chosen at random from commercial lots, were used. Either one cell or sets of soveral cells of the same kind were drained through a known constant resistor at a constant temperature. The voltage as 2. function of time was recorded using a double pen voltage-time recorder (Houston Instruments Omigraphic 2-3000). Two similar sets of cells were tested at the same time. One set was drained in an applied magnetic field while the second set was drained without the field. The initial experiment had the hookup leads soldered to the size $N$ cells. Subsequent experiments used copper tabs firmly taped to the cell ends or used non-magnetic alligator clips for contacts. With the size $D$ cells, the steel contact plates at both ends were removed, since these would distort the applied magnotic field. The size $\mathrm{N}$ cells have their cans bare and have a copper contact pressed over the carbon post. In all cases, the hookup leads ware kept the same length in the circuits of both sets. 


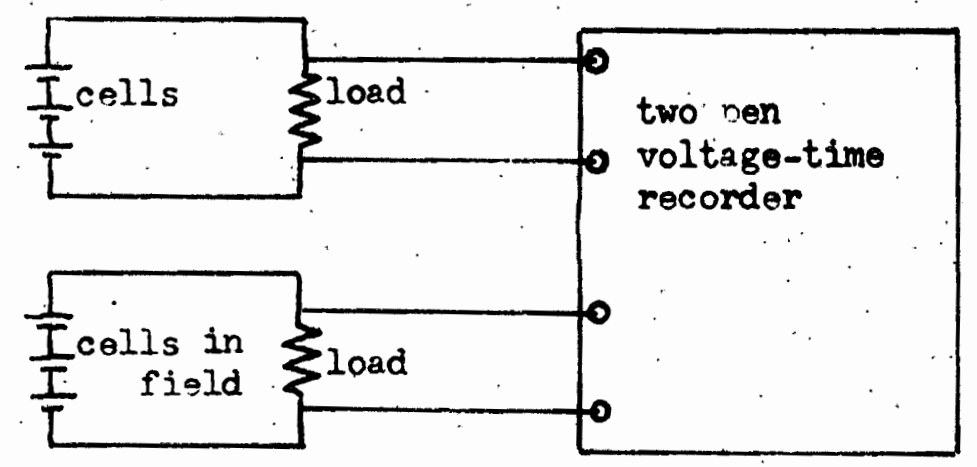

Figure 5. Schematic electrical circult for cell dischargo experiments. The number of cells in series varied from one to six. In one case (Experiment 9), the cells in the field and trose outside the fleld were in series across the resistance load (see Figure ?).

Temporature control was provided by bars of aluminum stock (at room temperature) or by ice-water batho. In the former case, the two cells or sats of cells were held in rhysical contact with an aluminum bar and wcre loeated at opposite ends of this bar. If the ice-water. bath was used, the individual cells were sealed in plastic bags to prevent an electrical short circuit through the water.

Orientation of the cells was either parallel or perpendicular to the appited field.

(a)

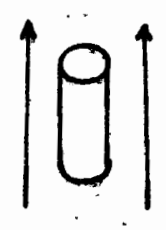

(b)

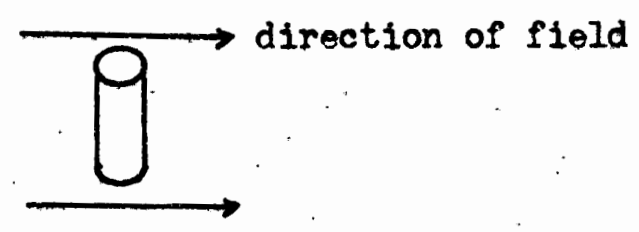

Figura 6. Cell alignment in the applied magnotic field: (a) the appliod field paraliel to the axis of the cells, and (b) the aodist field perpendicular to the axis of the cells. 
The resulting strip chart graph of voltage versus time was integrated numerically in time interval segments to give the total amount of energy output from the cells,

$$
E=\int P d t=\frac{1}{R} \int V^{2} d t=\frac{\tau}{3 R} \sum\left(v_{f}^{2}+v_{1} v_{f}+v_{i}^{2}\right)
$$

wher $=\tau$ is the time interval used, $R$ is tho resistance load, $V_{1}$ is the initial voltage of the segment considered, and $v_{f}$ is the final voltage of tho same segmont (see Appendix A for derivation). The summation is over all time segmonts.

The amount of charge passed was calculated (Appendix A) from the same strip chart graph according to."

$$
Q=\frac{1}{R} \int V d t=\frac{\tau}{2 R} \sum\left(v_{1}+v_{f}\right)
$$

One experiment was porformed in a different manner. In Experiment 9. the two sets of cells were connected together in series (see Figure 7). In this manner, the current through both sets of cells is the same.

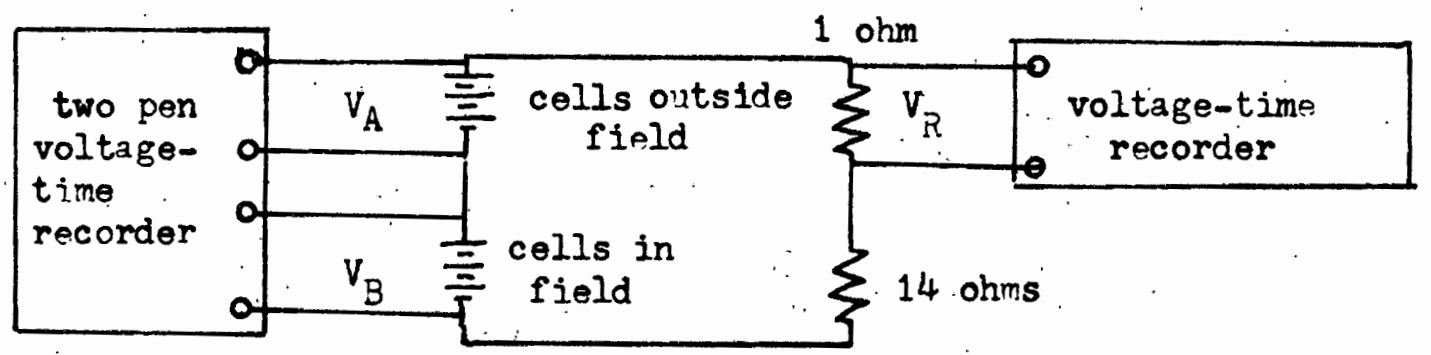

Figure 2. Schematic circuit of Experiment 9. The cells in the field and those outside the field were connected in series across a common resistance load. This load was made up of two known resistances, one of which $(R)$ had its voltage drop $\left(V_{R}\right)$ recorded. A two pen voltage-time recorder plotted the potential differences. $V_{B}$ and $V_{A}$, versus time of the cells drained with and without an applied magnetic field, respectively. 
The energy outout and charge passed for the sot of cells in Exporim 9 drained without the field was calculated according to,

$$
E_{A}=\int P d t=\int I V d t=\frac{\tau}{\sigma R} \sum\left(2 V_{R i} V_{A i}+V_{R i} V_{A f}+V_{R f} V_{A i}+2 V_{R f} V_{A f}\right)
$$

and for the charge passed;

$$
Q_{A}=\int I d t=\frac{1}{R} \int V d t=\frac{\tau}{2 R} \sum\left(V_{R i}+v_{R f}\right)
$$

where $V_{R i}$ and $V_{R f}$ are the initial and final voltage drops across $R$ for the time segment considered, $V_{A i}$ and $V_{A f}$ are the initial and final potential differences of the cells for the same timo segment, and $\tau$ is the length of tho time segment (see Appendix B). The energy output and charge passed for the set drained with an applied magnetic field is calculated similarly:

\section{RESULTS}

The results of the experiments measuring the energy output and charge passed by the Leclanché cells with and without an applied magnetic field are given in Table I.

Experiments are labeled 1 through 26. The type of cells ased wre, for size N, Mallory M91 OF and Eveready 904, and, for size D, Burgess 210 and Everesdy 950. The different types of magnets supplying the field are listed as I, II, III, IV, and V (soe Appendix C for illustrations). The magnets are as follows:

I......Varian Associatos, electromagnat model V-40n? with six inch pole pieces

II......Westinghouse, permanent horșeshoe magnet

III.... Edmund Scientific, permanent ring magnet $\# 30730$ 
T43LE I

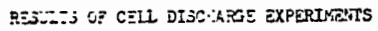

\begin{tabular}{|c|c|c|c|c|c|c|c|c|c|c|c|c|}
\hline 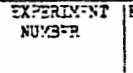 & $\begin{array}{l}\text { FIELD } \\
(\mathrm{KG})\end{array}$ & $\begin{array}{l}\text { WAGNET } \\
\text { TIPB }\end{array}$ & $\begin{array}{l}\text { NURBRR } \\
\text { OF CELLS }\end{array}$ & A.D YIPE & $\begin{array}{c}\text { RESISTR.icE } \\
\text { LORD } \\
\text { (ohms) }\end{array}$ & (xinutes) & $\begin{array}{l}\text { GaI =iTa IION } \\
\text { (of cells } \\
\text { in }(1 \cdot 1 d)\end{array}$ & $\begin{array}{l}\text { TSIPTERTURE } \\
\left({ }^{\circ} \mathrm{C}\right)\end{array}$ & $\begin{array}{l}\text { XIEPGY } \\
\text { OJfFUT } \\
\text { (joulps) }\end{array}$ & $\begin{array}{l}\text { ENERGY } \\
6 \text { IRCREASE } \\
\text { WITR FIDID }\end{array}$ & $\begin{array}{l}\text { C:ARGE } \\
\text { PASSED } \\
\text { (coulombs) }\end{array}$ & $\begin{array}{l}\text { CiihiGE } \\
\text { \& INCREASR } \\
\text { WITH FIEID }\end{array}$ \\
\hline 1 & $\begin{array}{l}4.5 \\
0\end{array}$ & I & $\begin{array}{l}6 \\
6\end{array}$ & $\begin{array}{l}\text { N. } \\
\text { *. }\end{array}$ & $\begin{array}{ll}60 & 13 \\
60 & 18\end{array}$ & $\begin{array}{l}600 \\
603\end{array}$ & carellel & 0 & $\begin{array}{l}2,900 \\
2,590\end{array}$ & +128 & $\begin{array}{l}1.060 \\
1.010\end{array}$ & $+5.0 \bar{A}$ \\
\hline 2 & $\begin{array}{l}4.5 \\
0\end{array}$ & $I$ & 1 & $\begin{array}{l}\text { D. } 210 \\
\text { D. } 210\end{array}$ & $\begin{array}{ll}4.6 & 1 . \\
4.6 & 1 \ldots\end{array}$ & $\begin{array}{l}1380 \\
1080\end{array}$ & cartand. & 22 & $\begin{array}{l}12,900 \\
12,000\end{array}$ & +7.48 & $\begin{array}{l}12,900 \\
: 2.300\end{array}$ & +4.96 \\
\hline 3 & $\begin{array}{l}4.5 \\
0 \\
\end{array}$ & $I$ & 1 & $\begin{array}{l}\text { D. } 210 \\
\text { D. } 210 \\
\end{array}$ & $\begin{array}{l}7.61 \% \\
4.6 \quad 18 \\
\end{array}$ & $\begin{array}{l}1230 \\
1030 \\
\end{array}$ & porpend. & 22 & $\begin{array}{l}19.479 \\
11.500\end{array}$ & -9.68 & $\begin{array}{l}11,200 \\
12.000\end{array}$ & -6.76 \\
\hline 4 & $\begin{array}{l}4.5 \\
0 \\
\end{array}$ & $I$ & 1 & $\begin{array}{l}\text { D, } 210 \\
\text { D. } 210\end{array}$ & $\begin{array}{l}4.611 \\
4.61 \mathrm{f}\end{array}$ & $\begin{array}{l}1030 \\
1050\end{array}$ & perpont. & 27 & $\begin{array}{r}: 2.000 \\
11.600\end{array}$ & +3.48 & $\begin{array}{r}12.300 \\
12,100 \\
\end{array}$ & +1.78 \\
\hline 5 & $\begin{array}{l}3.3 \\
0\end{array}$ & I & $\begin{array}{l}6 \\
6 \\
\end{array}$ & $\begin{array}{l}\text { D. } 950 \\
\text { D, } 950 \\
\end{array}$ & $\begin{array}{l}4.6 \div 8 \\
4.618\end{array}$ & $\begin{array}{l}990 \\
930\end{array}$ & parallel & 0 & $\begin{array}{l}32,400 \\
32,500\end{array}$ & -0.38 & $\begin{array}{r}17,100 \\
23,800 \\
\end{array}$ & +245 \\
\hline 6 & $\begin{array}{l}3.3 \\
0 \\
\end{array}$ & $I$ & 6 & $\begin{array}{l}\text { D, } 950 \\
\text { D, } 950\end{array}$ & $\begin{array}{l}4.612 \\
4.616\end{array}$ & $\begin{array}{l}1640 \\
1640\end{array}$ & parallel & 0 & $\begin{array}{l}35.500 \\
\angle 8,000\end{array}$ & +278 & $\begin{array}{r}20.300 \\
17.500\end{array}$ & $+16 \%$ \\
\hline 7 & $\begin{array}{l}3.3 \\
0\end{array}$ & $I$ & $\begin{array}{l}6 \\
6\end{array}$ & $\begin{array}{r}0,950 \\
\therefore \quad 0,950 \\
\end{array}$ & $\begin{array}{c}1.0526 \\
1.0521 \\
.1\end{array}$ & $\begin{array}{l}960 \\
960\end{array}$ & para2lel & 0 & $\begin{array}{l}11,900 \\
3,150\end{array}$ & $+46 x$ & $\begin{array}{l}19.000 \\
15.600\end{array}$ & $+19 \%$ \\
\hline 9 & $\begin{array}{l}3.3 \\
0\end{array}$ & I & $\begin{array}{l}6 \\
6\end{array}$ & $\begin{array}{l}\text { D. } 950 \\
D .950\end{array}$ & $\begin{array}{l}1.0526 \\
1.0525\end{array}$ & $\begin{array}{l}620 \\
620\end{array}$ & paraile1 & 0 & $\begin{array}{r}11,900 \\
9,600\end{array}$ & $+24 \overrightarrow{\%}$ & $\begin{array}{l}17,400 \\
14,900\end{array}$ & +171 \\
\hline$i$ & $\begin{array}{l}3.3 \\
1 \\
\end{array}$ & $I$ & $\begin{array}{l}6 \\
6\end{array}$ & $\begin{array}{l}\text { D. } 750 \\
\text { D. } 950 \\
\end{array}$ & 1515 & $\begin{array}{l}540 \\
340\end{array}$ & parell-1 & 0 & $\begin{array}{r}44,700 \\
30,490 \\
\end{array}$ & +478 & $\begin{array}{l}14.100 \\
14.100\end{array}$ & \\
\hline 10 & $\begin{array}{l}1.5 \\
0\end{array}$ & II & $\begin{array}{l}3 \\
3 \\
\end{array}$ & $\begin{array}{l}N, 934 \\
N, 904 \\
\end{array}$ & $\begin{array}{ll}30 & 17 \\
30 & 17\end{array}$ & $\begin{array}{l}1030 \\
1030 \\
-0 .\end{array}$ & perellol & 0 & $\begin{array}{l}1.790 \\
1.900\end{array}$ & -0.61 & $\begin{array}{l}1.305 \\
1.340\end{array}$ & -3.06 \\
\hline 11 & $\begin{array}{l}1.5 \\
0\end{array}$ & II & $\begin{array}{l}3 \\
3 \\
\end{array}$ & $\begin{array}{l}N, 5 \infty \\
N, 904 \\
\end{array}$ & $\begin{array}{r}3517 \\
3018\end{array}$ & $\begin{array}{l}609 \\
600\end{array}$ & parall 1 & 0 & $\begin{array}{l}1.730 \\
1.930\end{array}$ & $-5.5 \%$ & $\begin{array}{l}1,130 \\
1.170\end{array}$ & $+0.8 x$ \\
\hline 12 & $\begin{array}{l}1.0 \\
0\end{array}$ & III & $\begin{array}{l}3 \\
3\end{array}$ & $\begin{array}{l}\text { N. } 904 \\
\text { N. } 904\end{array}$ & $\begin{array}{ll}30 & 15 \\
30 & 16\end{array}$ & $\begin{array}{l}1030 \\
1050\end{array}$ & parellol & 0 & $\begin{array}{l}2,120 \\
2,170\end{array}$ & : -2.26 & $\begin{array}{l}1,480 \\
1,430 \\
\end{array}$ & $+3.5 \frac{1}{6}$ \\
\hline 13 & $\begin{array}{l}1.0 \\
0\end{array}$ & III & $\begin{array}{l}3 \\
3 \\
-\end{array}$ & $\begin{array}{l}\mathrm{N}, 904 \\
\mathrm{~N}, 924 \\
\end{array}$ & $\begin{array}{r}3018 \\
3018\end{array}$ & $\begin{array}{r}1020 \\
1220 \\
. \quad\end{array}$ & parallel & 0 & $\frac{1.720}{1.790 .}$ & $1-3.98$ & $\begin{array}{l}1.320 \\
1.360\end{array}$ & -2.98 \\
\hline 14 & $\begin{array}{l}1.0 \\
0\end{array}$ & IV & $\begin{array}{l}2 \\
2\end{array}$ & i: 924 & $\begin{array}{ll}30 & 16 \\
30 & i z\end{array}$ & $\begin{array}{l}1020 \\
1020\end{array}$ & parellel & 0 & $\begin{array}{l}1.640 \\
1.630 \\
\end{array}$ & +0.68 & $\begin{array}{l}1.360 \\
1.340 \\
\end{array}$ & +1.58 \\
\hline 15 & $\begin{array}{l}1.5 \\
0\end{array}$ & II & $\begin{array}{r}3 \\
3 \\
\end{array}$ & $\begin{array}{l}\text { N. } 9 x_{4} \\
\text { s. } 9 x_{4}\end{array}$ & $\begin{array}{l}1.052 \\
1.045\end{array}$ & $\begin{array}{l}1280 \\
1090\end{array}$ & parallel & 0 & $\begin{array}{l}174 \\
195 \\
\end{array}$ & $-11 x$ & $\begin{array}{l}1.660 \\
1.580 \\
\end{array}$ & $+5.1 \%$ \\
\hline 16 & $0^{1.7}$ & I & 6 & $\begin{array}{r}N, 924 \\
N, 904\end{array}$ & $\begin{array}{l}59.6 \\
60.0\end{array}$ & $\begin{array}{l}220^{\circ} \\
220 \\
. .\end{array}$ & prajlol & 0 & $\begin{array}{r}2.320 \\
2.160\end{array}$ & +7.48 & $\begin{array}{l}612 \\
586\end{array}$ & $\$ 4.4 \%$ \\
\hline 17 & $\begin{array}{l}1.1 \\
0 \\
\end{array}$ & v & $\begin{array}{l}6 \\
6\end{array}$ & $\begin{array}{l}N, 9 x_{4} \\
N, 9 x_{4}\end{array}$ & $\begin{array}{l}59.6 \\
60.0 \\
\end{array}$ & $\begin{array}{l}1020 \\
1027\end{array}$ & parallol & 22 & $\begin{array}{l}4.750 \\
4.630\end{array}$ & +2.67 & $\begin{array}{l}1.550 \\
1.570\end{array}$ & -1.36 \\
\hline 18 & $\begin{array}{l}1.1 \\
0\end{array}$ & $y$ & $\begin{array}{l}6 \\
6\end{array}$ & $\begin{array}{l}\text { N. } 9 \gamma_{1} \\
\text { H. } 94_{4}\end{array}$ & $\begin{array}{l}59.6 \\
69.0\end{array}$ & $\begin{array}{l}720 \\
720\end{array}$ & Frellal & 22 & $\begin{array}{l}4.620 \\
4.700 \\
\end{array}$ & -1.76 & $\begin{array}{l}1,460 \\
1,1600 \\
\end{array}$ & of \\
\hline 19 & $\begin{array}{l}1.1 \\
0\end{array}$ & $\begin{array}{l}v \\
\cdots\end{array}$ & $\begin{array}{l}6 \\
6\end{array}$ & $\begin{array}{l}\mathrm{N}, 924 \\
\mathrm{~N}, 914\end{array}$ & $\begin{array}{r}59.6 \\
60.0 \\
\ldots\end{array}$ & $\begin{array}{l}1000 \\
1000\end{array}$ & $a=a 1:=1$ & 22 & $\begin{array}{r}4,790 \\
4,860 \\
\end{array}$ & -1.48 & $\begin{array}{l}1.570 \\
1.570 \\
\end{array}$ & $x$ \\
\hline 20 & $\begin{array}{l}2.5 \\
0\end{array}$ & $\mathbf{v}$ & $\begin{array}{r}3 \\
3 \\
\end{array}$ & $\begin{array}{l}\text { N. } 9 x^{4} \\
\text { B. } 904\end{array}$ & $\begin{array}{l}30.2 \\
30.1 \\
\end{array}$ & $\begin{array}{l}1000 \\
1000 \\
\end{array}$ & porpend. & 22 & $\begin{array}{l}2,370 \\
2,340\end{array}$ & +1.38 & $\begin{array}{l}1.560 \\
1.570\end{array}$ & -0.76 \\
\hline 21 & $\begin{array}{l}2.5 \\
0\end{array}$ & $v$ & $\begin{array}{r}3 \\
3 \\
\end{array}$ & $\begin{array}{l}\text { N, } 904 \\
\mathrm{~N}, 904 \\
\end{array}$ & $\begin{array}{l}30.1 \\
30.2\end{array}$ & $\begin{array}{l}1000 \\
1030\end{array}$ & per and. & 22 & $\begin{array}{r}2.400 \\
2.370 \\
\end{array}$ & +1.35 & $\begin{array}{l}1.560 \\
1.540 \\
\end{array}$ & $+1.3 x$ \\
\hline 22 & $\begin{array}{l}2.5 \\
0 \\
\end{array}$ & $v$ & $\begin{array}{r}3 \\
3 \\
\end{array}$ & $\begin{array}{l}N, 904 \\
N, 904 \\
\end{array}$ & $\begin{array}{l}30.1 \\
30.2\end{array}$ & $\begin{array}{l}1000 \\
1000\end{array}$ & perpend. & 22 & $\begin{array}{l}2,450 \\
2,310 \\
\end{array}$ & +6.18 & $\begin{array}{l}1,540 \\
1,540\end{array}$ & $0 x$ \\
\hline 23 & $\begin{array}{l}2.5 \\
0\end{array}$ & $v$ & $\begin{array}{l}3 \\
3 \\
\end{array}$ & $\begin{array}{l}N, 904 \\
\text { N. } 904\end{array}$ & $\begin{array}{l}9.13 \\
9.14 \\
\end{array}$ & $\begin{array}{l}1000 \\
1000 \\
\end{array}$ & perpend. & 22 & $\begin{array}{l}360 \\
365\end{array}$ & -1.48 & $\begin{array}{l}840 \\
B^{2} \pm 0\end{array}$ & $0 \%$ \\
\hline 24 & ${ }^{2.5}$ & $v$ & $\begin{array}{l}3 \\
3 \\
\end{array}$ & $\begin{array}{l}\text { N. } 904 \\
\text { B. } 904\end{array}$ & $\begin{array}{r}59.6 \\
60.0 \\
\end{array}$ & $\begin{array}{l}1000 \\
1000\end{array}$ & porperd. & 22 & $\begin{array}{r}2,990 \\
2,960 \\
\end{array}$ & +4.54 & $\begin{array}{l}1.440 \\
1.420 \\
\end{array}$ & +2.98 \\
\hline 25 & $\begin{array}{l}2.5 \\
0\end{array}$ & $v$ & 3 & $\begin{array}{l}x, 904 \\
x, 9 \times 4\end{array}$ & $\begin{array}{l}59.6 \\
60.0\end{array}$ & $\begin{array}{l}1000 \\
1000\end{array}$ & perbond. & 22 & $\begin{array}{l}2.860 \\
2,880\end{array}$ & -0.78 & $\begin{array}{l}1,400 \\
1,390\end{array}$ & +0.76 \\
\hline 26 & $\begin{array}{l}2.5 \\
0\end{array}$ & $\mathbf{v}$ & 3. & $\begin{array}{l}x, 904 \\
x, 934\end{array}$ & $\begin{array}{l}59.6 \\
69.0\end{array}$ & $\begin{array}{l}1002 \\
1000\end{array}$ & perpend & 22 & $\begin{array}{r}2,990 \\
2,370 \\
\end{array}$ & $+4.2 x$ & $\begin{array}{l}1.430 \\
1.400 \\
\end{array}$ & +2.14 \\
\hline
\end{tabular}

Resistors 25 ed in Exporisents 1 through 14 ars 11sted with their

porentage error. For Exporirents 15 through 26, the ralues listed are

thoso moasured with a cract

See hppend1x E for arror arsigels. 
IV..... Idmund Scientific, two permanent ring magnets \#30730

V.......Laboratories For Science, permanent magnet model "Varifiux"

For Experiment 1, a olot of the amount of charge passed versus time for the cells drained with and without an applied magnetic field is given in Figure 8. The energy output of these cells versus time is plotted in Figure 9.

Exporiments 5, 6, 7, 8, and 9 were performed using the same field strength of $3.3 \mathrm{kG}$ (kilogauss), but for various load resistances. For these experiments, the amount of charge passed and tho energy output was recalculated for a common time of 620 minutes. These values are given in Table II. For these same experiments, graphs of charge passed and energy output per cell versus the resistance load per, cell have been plotted (see Figures 10 and 11 respectively).

\section{TABLE II}

DATA COMPUTED FOR EXPERIMENTS

5 THROUGH 9. TIME IS

620 MINUTES

$\begin{array}{cccccc}\text { EXPER IMENI } & \begin{array}{c}\text { FIELD } \\ (\mathrm{kG})\end{array} & \text { NUMBER OF CELLS } \begin{array}{c}\text { LOAD } \\ \text { (ohms) }\end{array} & \begin{array}{c}\text { CHARGE PASSED } \\ \text { (coulombs) }\end{array} & \begin{array}{c}\text { ENERGY OUTPUT } \\ \text { (joules) }\end{array} \\ 5 & 3.3 & 6 & 4.6 & 14.400 & 30.600 \\ & 0 & 6 & 4.6 & 10.600 & 19.100 \\ 6 & 3.3 & 6 & 4.6 & 14.700 & 32.600 \\ & 0 & 6 & 4.6 & 12.800 & 26.000 \\ 7 & 3.3 & 6 & 1.05 & 16.300 & 11.900 \\ & 0 & 6 & 1.05 & 13.300 & 8.580 \\ 8 & 3.3 & 6 & 1.05 & 17.400 & 12.300 \\ & 0 & 6 & 1.05 & 14.900 & 9.900 \\ 9 & 3.3 & 6 & 15 & 11.800 & 39.400 \\ & 0 & 6 & 15 & 11.800 & 29.7 .00\end{array}$




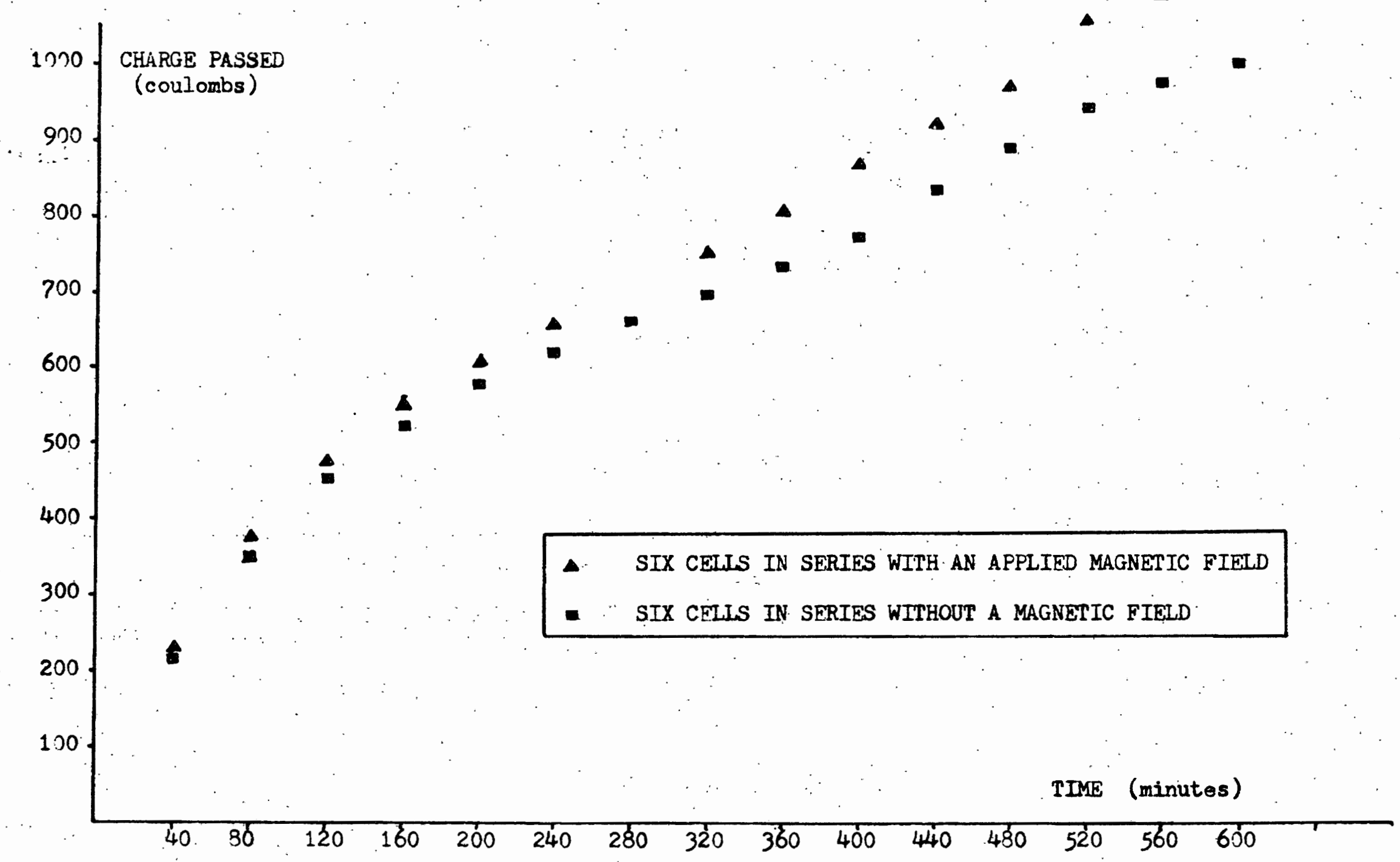

Figure 8. The effect of a magnetic field on the amount of charge passed by Leclanché cells (Exp. 1). 


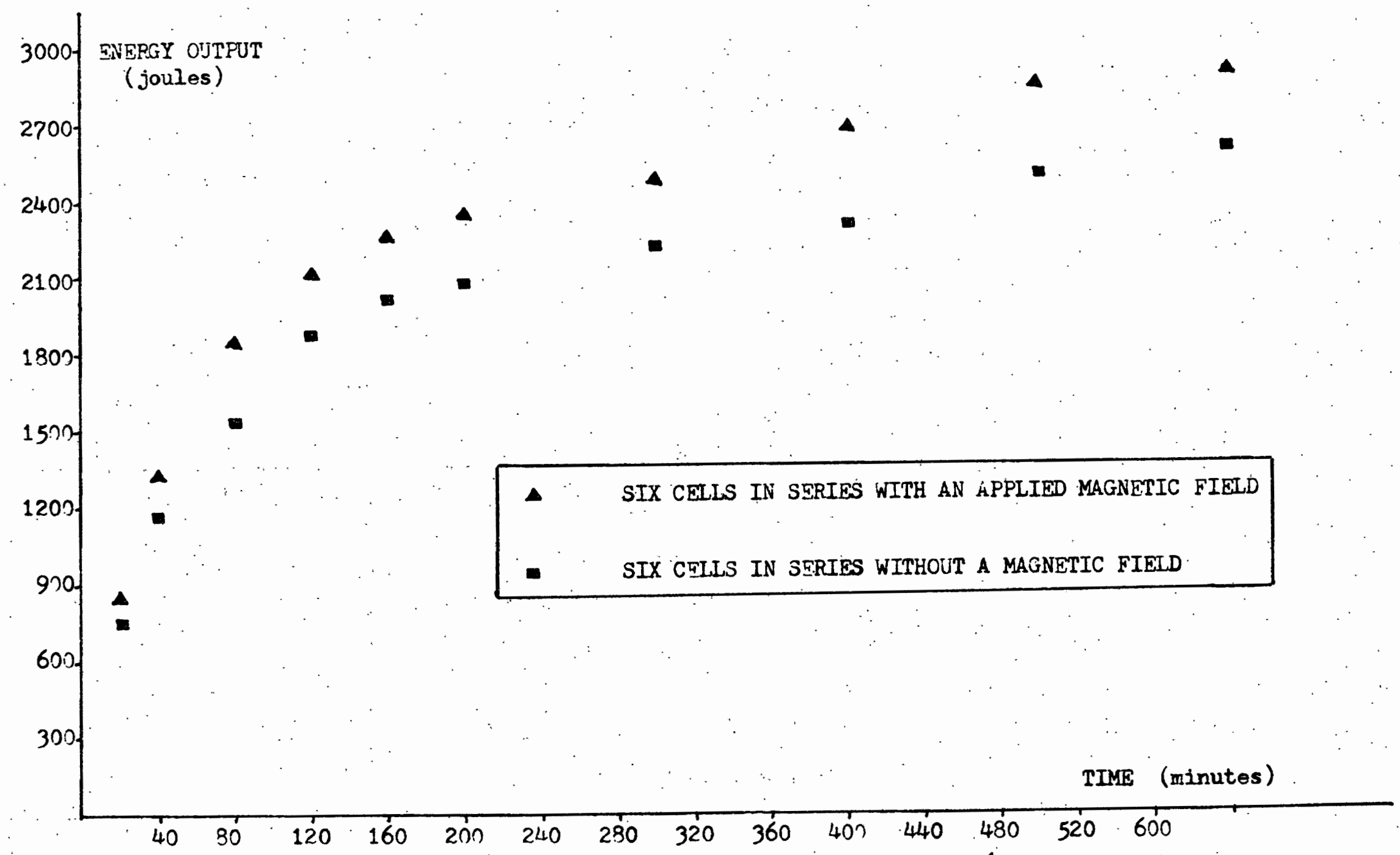

Figure 9. The effect of a magnetic field on the energy output of Leclanché cells (Exp. 1). 
CHARGE PASSED

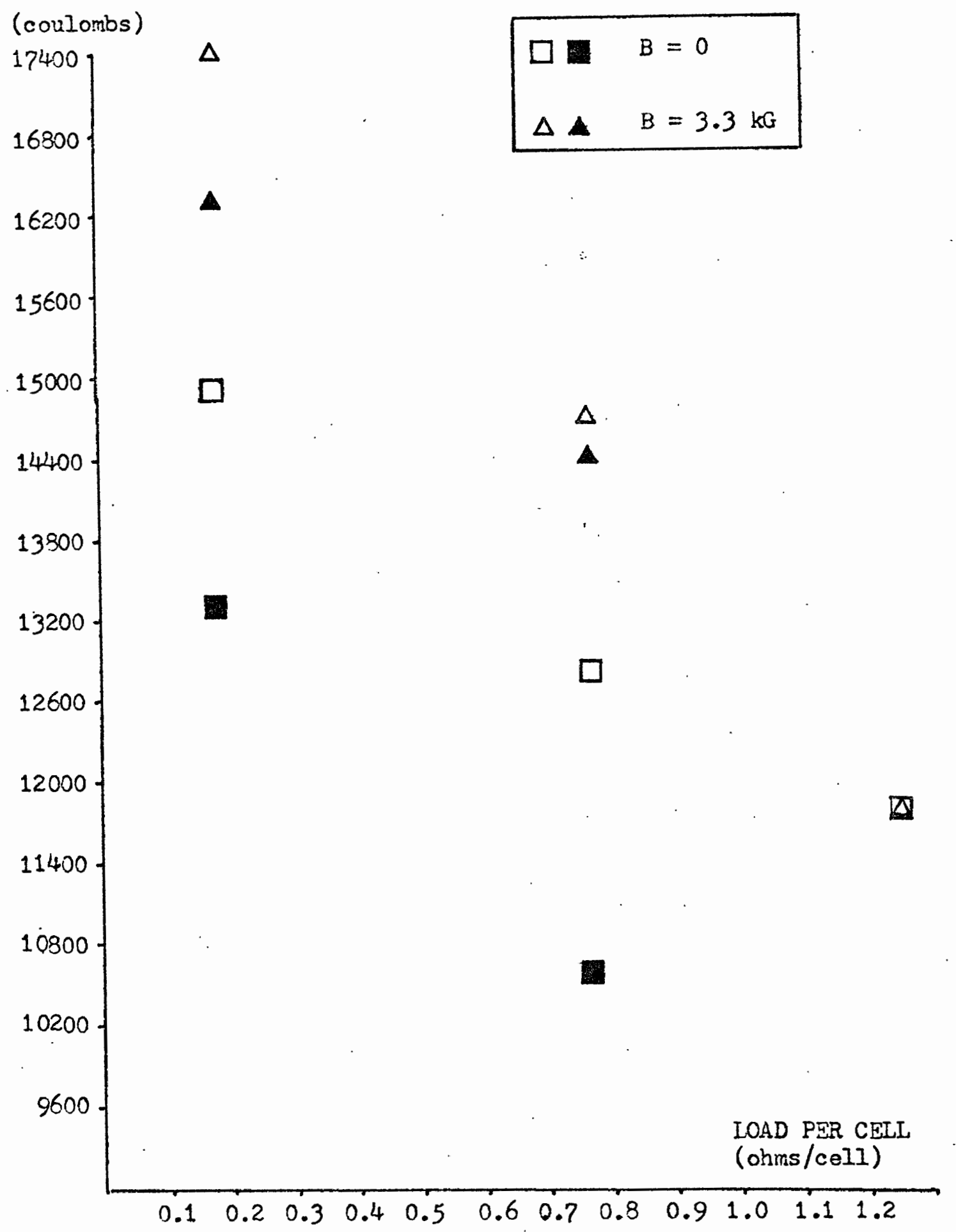

Figure 10. Graph of charge passed versus the resistance load per cell for Exporiments 5, 6, 7, 8, and 9. Time for each experiment was 620 minutes. Temperature was $0^{\circ} \mathrm{C}$. 
FNIRGY CUTPUT

PFR CELL

(joules/cell)

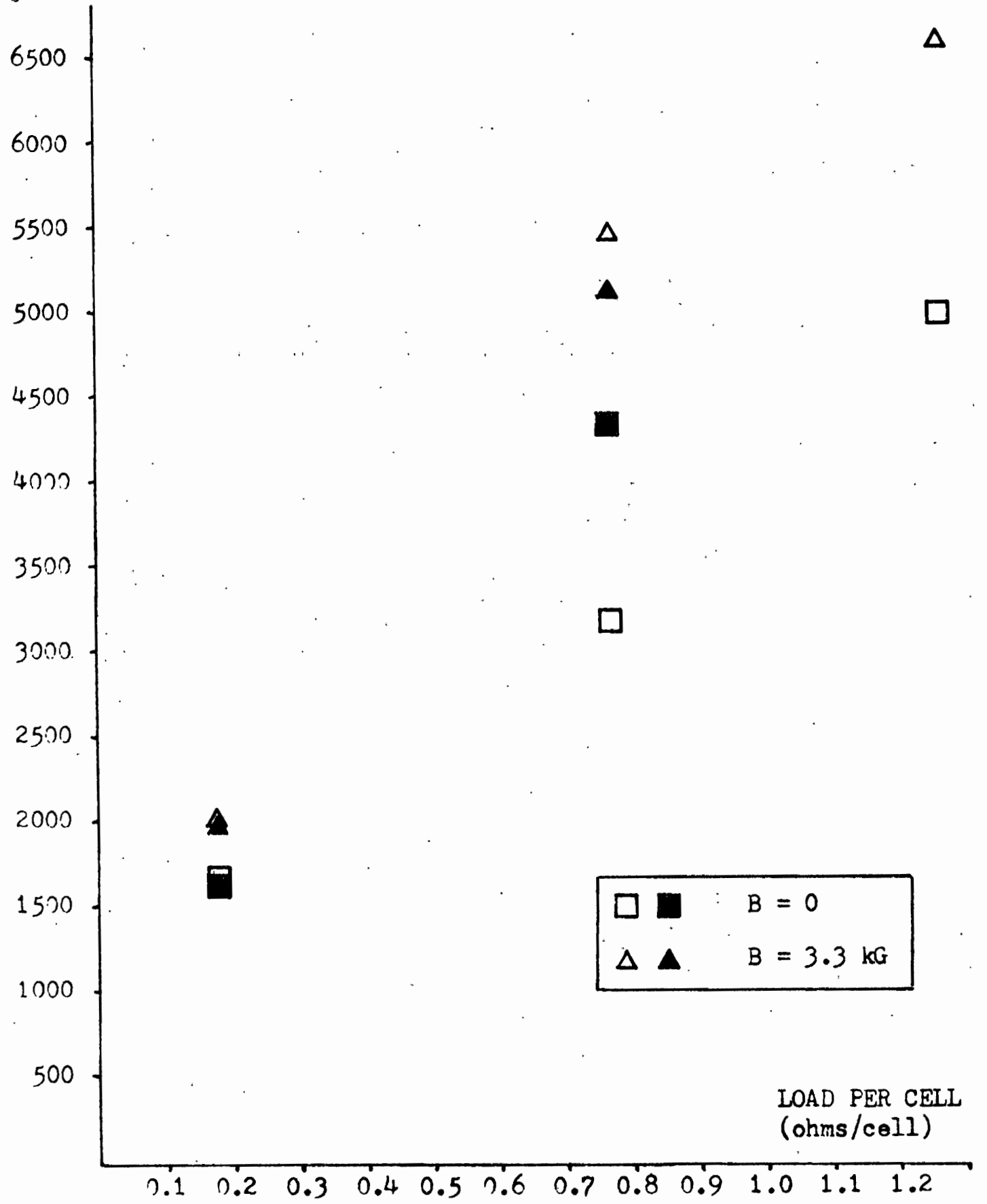

Figure 11. Graph of the enorgy output per cell vorsus the resistance load per cell for Experiments 5,6,7, 8, and 9. Time for each experiment was 620 minutes and the temperature was $0^{\circ} \mathrm{C}$. The cells in tho oxporiment at 1.25 ohms/cell were all in series (see page 10). 
During the operation of Experiment 8, a power failure turned off the electromagnet and opened the Leclanche cell circuits. During this intermuption, the cells were able to recover. The experiment was interrupted 346 minutes after its start and the length of the interruption was 534 minutes. The power was then reapplied and the experiment allowed to continue. In Table III, there is listed the values of the voltages across each set before and after the intermuption of the experiment.

\section{TABLF: III}

VOLTAGES ACROSS EACH SET OF CELLS IN EXPFRIMFNT 8 BEFORE

AND AFT TR A 534 MINUTE INTFRRUPTION. EACH SET HAD BEEN CONNECTED TO A $1.05 \pm 2 \%$ OHM LOAD FOR A

PERIOD OF 346 MINUTES PRIOR TO THE

RECOVERY PERIOD

VOLTAGE BEFORE VOLTAGE AFTER. D INCREASE

\begin{tabular}{|c|c|c|}
\hline CELIS WITH FIELD & .322 volts & .810 volts \\
\hline CELLO NITHOUT FIELD & .275 volts & .570 volts \\
\hline
\end{tabular}

Experiment 9 is unique in that it was the only experiment mun with the two sets of cells in series (see Figure 7.). The energy output and charge passed were calculated in this experiment only for the first 840 minutes. This was due to the voltage across the cells drained without an applied magnetic field dropping to zero at the end of this period (see Figure 12). The experiment was allowed to continue beyond this point and for a porlod of 130 minutes the potential across the cells outside tho field was some unmeasured negative value. For the next 210 minutes, the potentiel across this set of cells was again positive. The experiment was then ended. 


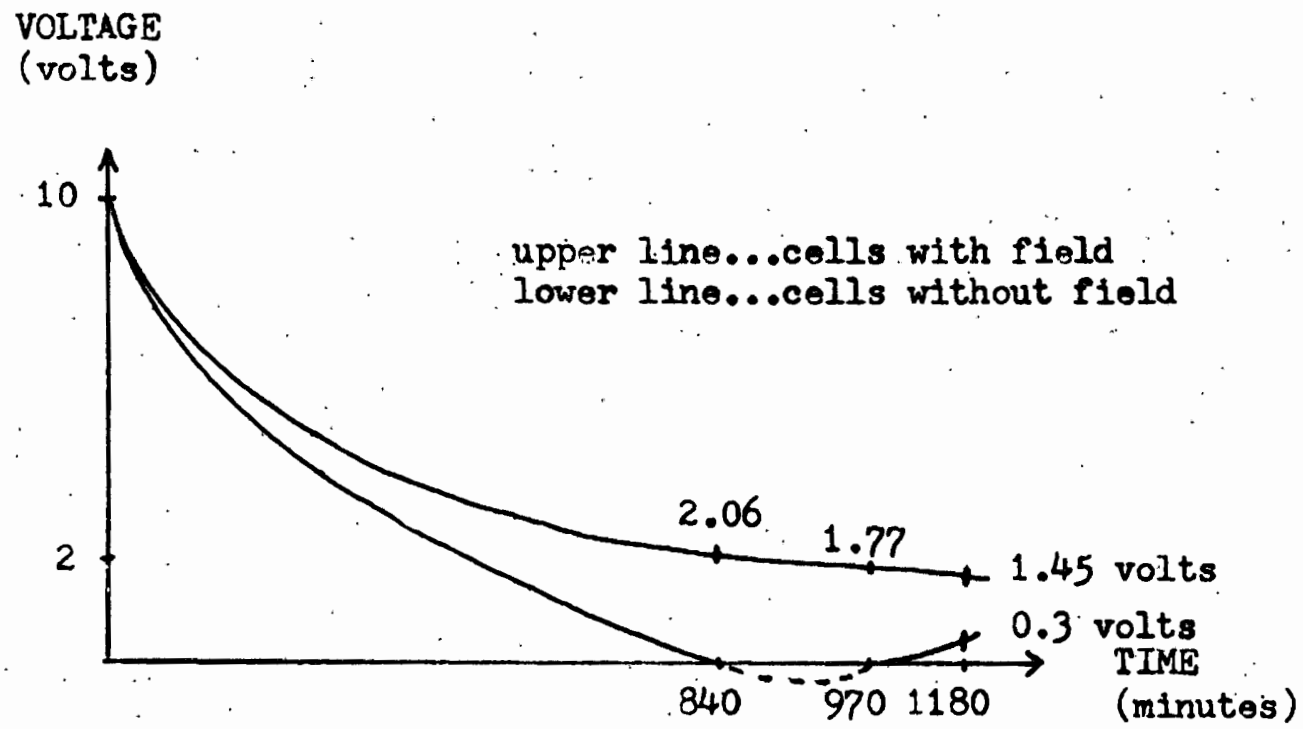

Figure 12. Rough plot of voltage versus-elapsed time for Experiment 9. The two sets of six cells were wired in series with a 15 ohm resistance load. The field used was $3.3 \mathrm{kG}$. The dotted line indicates the section where no voltages were mensured. During this period, the cells without an applied field were acting as an additional losd for the set of cells positioned in the magnetic field.

It was stated in the Introduction that the removal of $\mathrm{MnOOH}$ by proton diffusion into the interior of the $\mathrm{MnO}_{2}$ particle is considered to bo the rate determining stop in the Leclanche cell. Therefore, a crude determination of the diffusion distance $(x)$ of the proton was calculated from the recovery time ( $t=130$ minutes) during which tho potential across the cells in Experiment 9 without an applied magnatic field was negative. The diffusion constant (D) for protons is $1.2 \times 10^{-18} \mathrm{~cm}^{2} / \mathrm{sec}$ (10). Then the diffusion distance (11) is

$$
\frac{x=\sqrt{2 D t}}{=\sqrt{2\left(1.2 \times 10^{-18} \mathrm{~cm}^{2} \sec ^{-1}\right)\left(9.8 \times 10^{3} \mathrm{sec}\right)}}
$$




$$
x=1.5 \times 10^{-7} \mathrm{~cm}
$$

This value corresponds to several molecular layers.

These rosults indicate a apparent increase in energy output and in the amcunt of charge passed when the cells are drained in an applied magnetic field. The total energy output of the Leclanché cells in Experiments 1 through 26 is 217 kilojoules for those drained in a field and 188 kilojoules for those without. This is a $15 \%$ difference in energy output. The percentage increase in the amount of charge passed was $9.0 \%$ with a total of 149,000 coulombs passed by those cells in the field and 136,000 coulombs for those without. The total number of Leclanche cells used in the 26 experiments was 202, with 101 being drained in an applied magnetic field and 101 without.

A marked difference is noted between the increased output of the size $D$ and size $N$ cells (sse Table IV). The latter have a relatively small increase in energy output and in the amount of charge passed with the appliod magnetic f1old. Anothor difference between the two cell sizes lias in the ratios of the volume of the cathodic material (V) to the surface area of the zinc (A) with which it is in contact. For the sise N cells, the approximate ratio is

$$
V / A=\left(2000 \mathrm{~mm}^{3} /\left(800 \mathrm{~mm}^{2}\right)=2.5\right.
$$

while for the size $D$ cells,

$$
V / A=\left(30,000 \mathrm{~mm}^{3}\right) /\left(5,000 \mathrm{~mm}^{2}\right)=6
$$

If the bulk hydrodynamic mixing effects are negligible in the Leclanch' cell, then one possible contribution to the groater efficiency of the cell is the Inhibition by the magnatic field of hydrogen evolution at tho zinc anode. This might be expected if proton motion to cathodic 
TABLE IV

ENERGY OUTPUT AND CHAPGE PASSED FOR

SIZE N AND SIZE D CEILS SUMMED

OVER ALL EXPERIMENTS

\begin{tabular}{|c|c|c|c|c|c|c|c|c|}
\hline \multirow{2}{*}{$\frac{\text { SIZE }}{N}$} & \multirow{2}{*}{$\begin{array}{l}\begin{array}{l}\text { NUMBER OF } \\
\text { EXPERIMENTS }\end{array} \\
18\end{array}$} & \multirow{2}{*}{$\begin{array}{l}\text { NUMBER } \\
\text { OF CELIS } \\
136\end{array}$} & \multicolumn{2}{|c|}{$\begin{array}{l}\text { ENERGY }(\mathrm{J}) \\
D \text { NO FIELD }\end{array}$} & \multicolumn{2}{|c|}{$\begin{array}{l}\text { CHARGE (C) } \\
\text { NO FIELD }\end{array}$} & \multicolumn{2}{|c|}{$\begin{array}{l}\text { \& INCREASE } \\
\text { ENERGY CHARGE }\end{array}$} \\
\hline & & & 45.000 & 44,300 & 24.300 & 24.100 & 1.68 & 0.88 \\
\hline$D$ & 8 & 66 & 172,000 & 144,000 & 124.000 & 112,000 & 198 & $11 \%$ \\
\hline $\begin{array}{l}\text { all } \\
\text { cells }\end{array}$ & 26 & 202 & 217,000 & 138,000 & 149.000 & 136,000 & 158 & 9.08 \\
\hline
\end{tabular}


sites on the anode is impeded by the field. The zinc-oxidation/. hydrogen-reduction mechanism dass not directly influence the $\mathrm{zinc}-$ oxidation/manganese dioxide-reduction couple, but it does indirectly by increasing the amount of zinc ions being produced. This last increases the zinc ion concentration gradient, reducing its effective mobility and increasing the resistance of the cell. 
FURTHER INVESTIGATION OF THE LECIANCHÉ CELL

The positive relationship between an applied magnetic field and an increase in the energy output and in the amount of charge passed has been shown. However, the reasons for this effect are still uncertain. Assuming that the bulk hydrodynamic effect of mixing has been eliminated or reduced, investigations of corrosion is Leclanché cells with and without the presence of a magnetic field were attempted.

\section{HYDROGEN EVOLUTION}

As seen in Table I, an apnlied magnetic field of several kilogauss can increase the amount of charge passed by Leclanché cell through various resistance loads. If this is at least partly a result of the inhibition of hydrogen evolution, then discharging cells in a field should have measureably less hydrogen gas being disch rged than cells discharging under the same conditions outside the field.

Using the results of Experiment 1, a difference of about 50 coulombs passed was calculated for two sets of six cells being drained Into 60. ohms. This corresponds to

$$
2 \mathrm{H}^{+}+2 \theta^{-} \rightarrow \mathrm{H}_{2}
$$

$(2$ moles $)(96,500$ coulombs/mole $) \rightarrow(1 \mathrm{~mole})\left(2 \mathrm{grams} / \mathrm{mole}\right.$ of $\left.\mathrm{H}_{2}\right)$

$$
\begin{aligned}
50 \text { coulombs } & \longrightarrow 0.0005 \text { grams } \mathrm{H}_{2} . \\
& \approx 6 \mathrm{cc} \mathrm{H}_{2} \text { gas } \mathrm{STP}
\end{aligned}
$$

...saveral cubic centimsters of hydrogen gas, assuming that the greater amount of charge being passed in the cells inside the field is 
a result of the inhibition of hydrogen evolution. So if one were to soal the colls in a container, with a method of measuring volume or pressure change as the cells were drained, it should be possible to test the theory.

The basic approach was to seal the cells in a glass tube with wire leads entering by way of a water filled tube (see Figure 13) and to detect a change of volume by a column of water or mercury. A nitrogen atmosphere was used to suppress the accompanying reaction

$$
\mathrm{O}_{2}+4 \mathrm{H}^{+}+4 e^{-} \rightarrow 2 \mathrm{H}_{2} \mathrm{O}
$$

Alternately, the load resiator itself could be sealed in with the cells. No consistant results were obtained due to either leakage or lack of sensitivity, and this approach was abandoned.

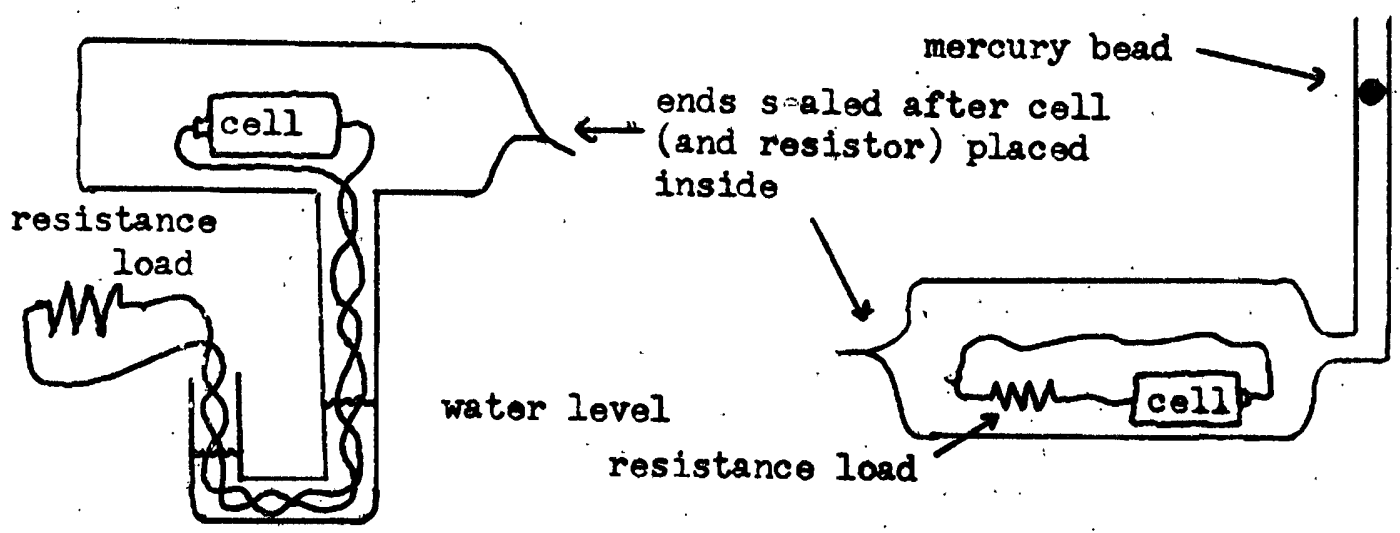

Figure 13. Basic approaches to the detection of hydrogen
evolution. 


\section{MASS CHANGE}

The reduction of oxygen (which enters the cell through the carbon rod) also increases the amount of zinc corrodsd:

$$
\begin{gathered}
\mathrm{Zn}=\mathrm{Zn}^{2+}+2 \mathrm{e}^{-} \\
\mathrm{O}_{2}+4 \mathrm{H}^{+}+4 \mathrm{e}^{-}=2 \mathrm{H}_{2} \mathrm{O}
\end{gathered}
$$

Another possible explanation of the increased charge passed may lie in less cell resistance due to an intibition of the above reduction. To investigate this possibility, size $D$ cells were stripped of their papor jackets and metal contact caps, and cleanod. Cells were placed in ice-water baths as in the cell discharge experiments and drained into constant resistance loads. Mass measurements were made of the cells before and after being drained but no consistant data was obtained. Data is given in Trble V. Difforences in the number of colls drained with and without on applied magnetic flold resulted from the discarding of cells that leaked electrolyte.

\section{TABLE V}

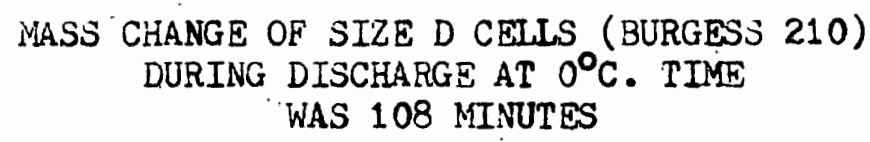




\section{EXTENT OF CORROSION}

Hydrogen evolution is part of the corrosion process for zinc in the Leclanché cell (9). Therefore, a crude measurement of the extent of corrosion of cells drained with and without an applied field was mads.

Thirty-six Eveready 950 size D cells (see Table I, experiments 6, 7. and 8) had been drained until the cell walls were pitted with holes. After discharging, the cells were cut apart and the cells flattened out. The bottom ends ware discarded as they were protected from extensive corrosion by a cupped kraft washer (see Fipure 3).

The flattened cell walls were then used to obtain a photographic contact print from which the open area of the zinc anodes was estimated. This was done by using a plastic sheet which had a grid network photographically laid on it. Theindividual squares on this grid had an unit area of $0.011 \mathrm{~cm}^{2}$. The 18 cells drained without the field had a total area of $11.9 \mathrm{~cm}^{2}$ eaten away compared to $25.8 \mathrm{~cm}^{2}$ for the cells without the field (see Table VI).

The increased area of corrosion of the cells in the magnetic field correlates qualitatively with the increased charge passed (see Tables I and VI). However, there is no way presently to quantitatively connact the amount of open area corroded to the amount of charge passed. This last is necessary to determine if there was an inhibition of corrosion due to the magnetic field or if the amount of open area is just a result of the amount of charge passed. 
TABLE VI

OPEN AREA OF LECLANCHÉ CELI CANS

CORRODED DUE TO DISCHARGE

\begin{tabular}{|c|c|c|c|c|c|c|c|}
\hline $\begin{array}{l}\text { EXPERIMENT } \\
\text { NUMBER }\end{array}$ & $\begin{array}{l}\text { FIELD } \\
\text { (KG) }\end{array}$ & $\begin{array}{l}\text { NUMBER OF } \\
\text { CELLS }\end{array}$ & $\begin{array}{l}\text { IOAD } \\
\text { (ohms) }\end{array}$ & $\begin{array}{c}\text { TIME : } \\
\text { (minutes) }\end{array}$ & $\begin{array}{l}\text { CHARGE PASSED } \\
\text { (coulombs) }\end{array}$ & $\begin{array}{l}A R E A \\
\left(\mathrm{~cm}^{2}\right) .\end{array}$ & $\begin{array}{l}\text { of INCREASE } \\
\text { WITH FIELD }\end{array}$ \\
\hline 6 & $\begin{array}{l}3.3 \\
0\end{array}$ & $\begin{array}{l}6 \\
6\end{array}$ & $\begin{array}{l}4.6 \\
4.6\end{array}$ & $\begin{array}{l}1640 \\
1640\end{array}$ & $\begin{array}{l}20.300 \\
17.500\end{array}$ & $\begin{array}{r}14.11 \\
6.10\end{array}$ & 768 \\
\hline 7 & $\begin{array}{l}3.3 \\
0\end{array}$ & $\begin{array}{l}6 \\
6\end{array}$ & $\begin{array}{l}1.05 \\
1.05\end{array}$ & $\begin{array}{l}960 \\
960\end{array}$ & $\begin{array}{l}19,000 \\
15,600\end{array}$ & $\begin{array}{l}5.01 \\
4.38\end{array}$ & 78 \\
\hline 8 & $\begin{array}{l}3.3 \\
0\end{array}$ & $\begin{array}{l}6 \\
6\end{array}$ & $\begin{array}{l}1.05 \\
1.05\end{array}$ & $\begin{array}{l}620 \\
620\end{array}$ & $\begin{array}{l}17.400 \\
14.900\end{array}$ & $\begin{array}{l}6.75 \\
1.48\end{array}$ & $280 \%$ \\
\hline
\end{tabular}


INVFSTIGATIONS OF THE CORROSION OF ZINC

\section{CORROSION EXPERIMFNTS}

In an electrochemical cell, interaction of the magnetic field with processes at both anode and cathode are possible. Furthor work, therefore, was concentrated on only one process, that of corrosion at the zinc anode, due to time limitations.

Specimens of zinc were allowed to corrode with and without an applied magnetic field in an electrolyte made up of ammonia chlorido and zinc chloride. These two chemicals are contained in the electrolyte used in the Leclanché cell. Change in mass of the specimens was moasured to determine the effect of the magnetic field on the corrosion process.

The electrolyte was made up with one mole of each of the above chemicals plus enough de-ionized water to make one liter of solution.

In all cases, the zinc specimens for each experiment. were cleaned and woighed in an identical manner. Four different experiments were performed.

Experimont A

Fighteen zinc discs (99.9\% pure with rospect to motalile impurities) were allowed to corrode in the $\mathrm{NH}_{4} \mathrm{Cl}-\mathrm{ZnCl}_{2}$ solution. The discs "rere $0.03 \mathrm{~cm}$ thick and $1.94 \mathrm{~cm}$ in diameter. They were washed with Labtone (Van Waters \& Rogers, Cat. No. 21850-003), rínsed with water, and then placed in an ultrasonic cleaner with distilled water for 5 
minutes. The specimens were then dried with a hot air gun. Nine of the discs were blaced horizontally in a $15 \mathrm{ml}$ beaker (Kimax \#14000) with one layer of Kinwipes material (Kimberly-Clark Corp., Stock No. 34150) between each disc. The beakers were filled to tha $10 \mathrm{ml}$ mark with the electrolyt3. The second group of nine discs were prepared in the same way. One group was left in a field of approximately 2 kilogauss, while the socond group of nine discs was allowed to corrode without a magnetic field. The magnet used was a Varian Associates model V-4004 electromagnet with 2 inch pole pieces.

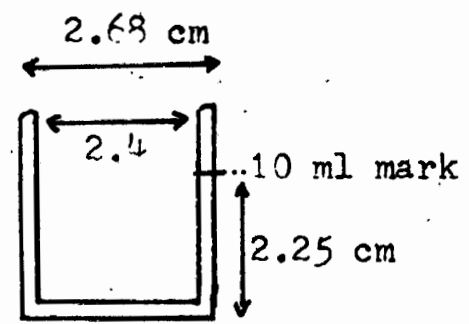

$15 \mathrm{ml}$ beaker Kimax \#14000

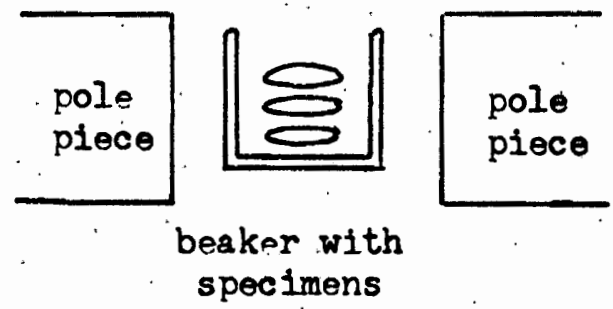

Figurs 14. Equipment and positioning of Experimsnt A.

The mass of the specimens ras measured before and after the experiment. Table VII gives the results of this experiment. The total change in mass is given with a positive amount indicating an increase in mass. Time for the experiment was $98 \frac{1}{2}$ hours.

\section{Expgriment $\mathrm{E}$}

Twenty-four rectangular zine strips ( $99.9 \%$ pure with respect to metallic impurities) of various dimansions were allowed to corrode in the electrolytic solution. The strips were arranged in three groups, 


\section{$\Gamma: 1=I Z V I I$}

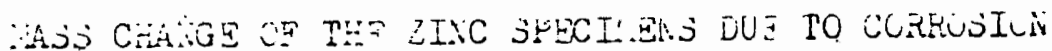

\begin{tabular}{|c|c|c|c|c|c|c|}
\hline EXPNRIMUNT & $\begin{array}{l}\text { FIELD } \\
(k G)\end{array}$ & $\begin{array}{c}\text { SPGCIMENS } \\
\text { (type })\end{array}$ & $\begin{array}{l}\text { NUNUBER OF } \\
\text { SFECIVEATS }\end{array}$ & $\begin{array}{c}\text { TOTHL } \\
\text { (grams) }\end{array}$ & TIYE & $\begin{array}{l}\text { PEMFERTURE } \\
\left({ }^{\circ} \mathrm{C}\right)\end{array}$ \\
\hline . & . & & & & . & \\
\hline$A$ & $\begin{array}{l}2 \\
0\end{array}$ & $\begin{array}{l}\text { discs } \\
\text { discs. }\end{array}$ & $\begin{array}{l}9 \\
9\end{array}$ & $\begin{array}{l}-0.01276 \\
-0.01133\end{array}$ & $\begin{array}{l}98 \frac{1}{2} \text { hours } \\
98 \frac{1}{2} \text { hours }\end{array}$ & $\begin{array}{l}22 \\
22\end{array}$ \\
\hline 3 & $\begin{array}{c}2 \text { top } \\
2 \text { bottom } \\
0\end{array}$ & $\begin{array}{l}\text { rectanglos } \\
\text { roctangles } \\
\text { rectangles }\end{array}$ & $\begin{array}{l}8 \\
8 \\
8\end{array}$ & $\begin{array}{l}-0.02518 \\
-0.02337 \\
-0.72573\end{array}$ & $\begin{array}{l}7 \text { days } \\
7 \text { days } \\
7 \text { days }\end{array}$ & $\begin{array}{l}22 \\
22 \\
22\end{array}$ \\
\hline C. & 4.5 & $\begin{array}{l}\text { cans } \\
\text { cans }\end{array}$ & $\begin{array}{l}10 \\
11\end{array}$ & $\begin{array}{l}+0.0063 \\
+0.0076\end{array}$ & $\begin{array}{l}7 \text { days } \\
7 \text { : days }\end{array}$ & $\begin{array}{l}22 \\
22\end{array}$ \\
\hline$\Sigma$ & $\begin{array}{c}1.5 \text { top } \\
0\end{array}$ & $\begin{array}{l}\text { rectangles } \\
\text { roctangles }\end{array}$ & $\begin{array}{l}4 \\
4\end{array}$ & $\begin{array}{l}-0.0151 \\
-0.0076\end{array}$ & $\begin{array}{l}7 \text { days } \\
7 \text { days }\end{array}$ & $\begin{array}{l}22 \\
22\end{array}$ \\
\hline
\end{tabular}


Aach of which contained the following zinc strips:

2 strips: $15.2 \mathrm{~cm} \times 1.27 \mathrm{~cm} \times 0.7 \mathrm{~cm}$

2 strips: $15.2 \mathrm{~cm} \times 1.27 \mathrm{~cm} \times 0.3 \mathrm{~cm}$

4 strips: $15.2 \mathrm{~cm} \times 0.91 \mathrm{~cm} \times 0.3 \mathrm{~cm}$

Each group made up of the above strips were cleaned as in Experiment $A$ and placed in a $25 \mathrm{ml}$ graduated cylinder (Pyrex \#3075) with a strip of Kimwipes material between oach strip. The cylinders were filled with the electrolyte to one inch above the top of the specimens. One group was left to corrode with a field centered at the bottom odge of the strips, one with the field at the top edge of the strips, and the remaining group with no applied magnotic field.

As mentioned before, the corrosion of zinc involves an oxidation and a reduction reaction. Two possible reductions are that of $\mathrm{H}^{+}$and of $\mathrm{O}_{2}$. The latter would be influenced by tho depth in the solution at which tho corrosion occurred. The field was apolied at two regions of the zinc strip to determine if there exists an interaction between the field and $\mathrm{O}_{2}$ reduction. A difference in depth should, therefore, vary the strength of such an interaction, if all other factors are unchanged.

Time was one weok. The magnet used was a Varian Associates model

-V-40.94 electromagnet with 2 inch pole pieces. Field was approximately $2 \mathrm{kG}$. Results are given in Table VII and the experimental equipment is diagramed in Figure 15.

Experiment C.

In this experiment, the zinc containers from Eveready 904 cells were filled with $1 \mathrm{ml}$ of the $\mathrm{NH}_{4} \mathrm{Cl}_{2}-\mathrm{ZnCl}_{2}$ solution and tested for the offect of a magnatic field on corrosion. 


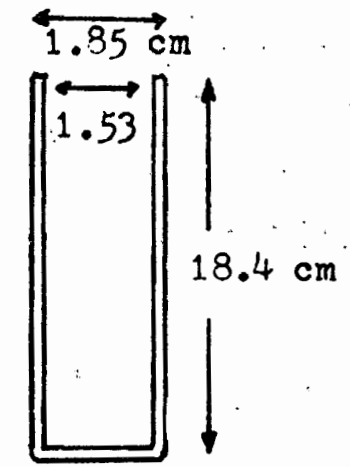

graduated cylinder Pyrex \#3075
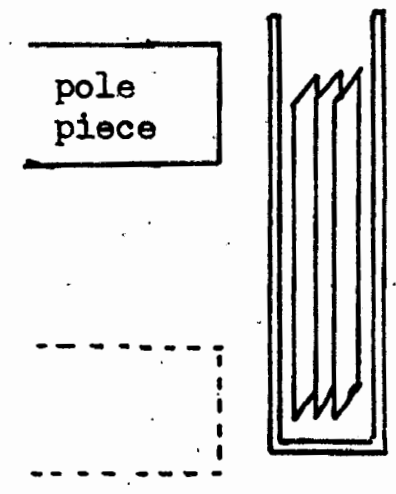

magnet positioned

at top edge

magnet positioned

i at bottom edge

i.......

Figure 15. Equipment and position of magnetic field in Experiment $B$.

The cells used were cut open at the top and the inside materials romoved. The cans were then cleaned with Labtone, rinsed, and then placed in a zinc cleaning solution for one minute. This cleaning solution was made up of 100 grams of chromic acid, $7 \frac{1}{2}$ grams of sodium sulphate. $25 \mathrm{ml}$ of nitric acid and $475 \mathrm{ml}$ of distilled water. The zinc cans were then re-rinsed and placed in an ultrasonic cleaner with distilled water and finally rinsed again in distilled water. The cans were then each dried with a hot air gun for 10 seconds.

The can size was $7 / 16$ inches in diameter and 3/4 inches high. An aluminuin bar was drilled with two sets of holes, one at either end, to serve as a heat sink and holder for the cans. Once divided into two sroups and placed in either end of the aluminum bar. the cans were filled with one $\mathrm{ml}$ of the electrolyte (using a $1 \mathrm{ml}$ calibrated pipette). One $m$ l of electrolyte filled the zinc cans to a depth of approximately $1.0 \mathrm{~cm}$. A magnetic field was centered on the zinc cans at one end of 
the aluminum bar while the other set of cans was left to corrode without an applied field. The magnet used was a Varian Associates model V-4007 with 6 inch pole pieces. The field strength was $4.5 \mathrm{kG}$.

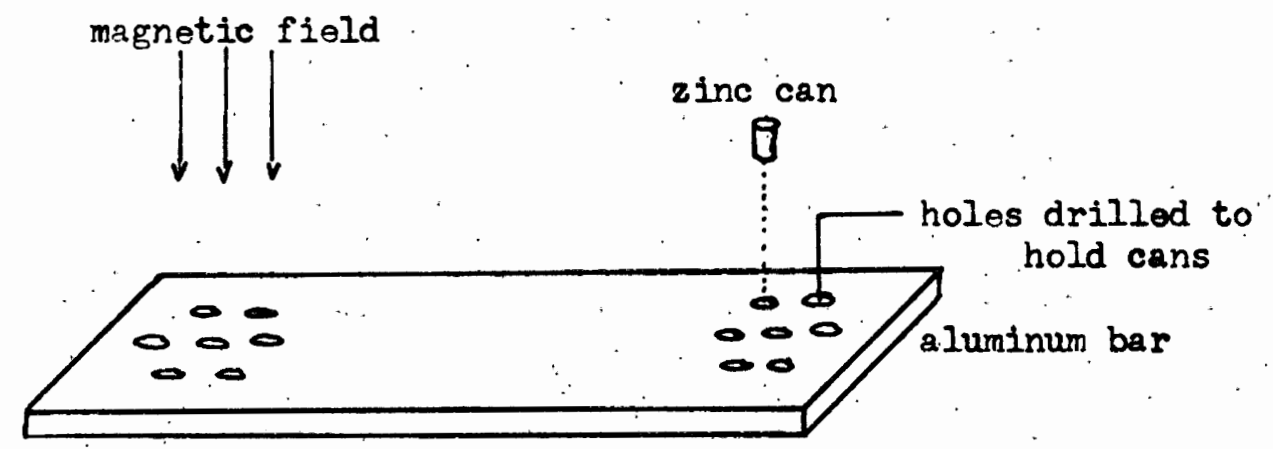

Figure 16. Position of apperatus in Experiment $C$.

After a poriod of one week, the cans wore removed, rinsed, placed in an ultrasonic cleaner for 5 mimutes, and re-rinsed, all with distilled water. Then each can was dried with a hot air gun for 10 seconds and re-weighed. In Table VIII are listed the individual mass changes, together with the mean, average deviation, and standard deviation of each group of cans.

At the completion of the experiment, the cans were cut open (see Figure 17) and inspected. A dividing line of variable clarity was observed, separating the inside surface of the zinc cans into two regions, one which was in contact with the electrolyte and the other which was exposed only to air. In both groups, the liquid-air line on the flattened cans show a visual increase in width with an incresse in 


\section{TABLE VIII}

\section{INDIVIDUAL DATA FOR ZINC CANS}

IN EXPERIMENT $C$

$\begin{array}{ccc} & \text { FIELD } & \text { NO FIELD } \\ \text { INDIVIDUAL MASS CHANGES } & -0.0051 & -0.0031 \\ \text { (grams) } & -0.0040 & -0.0023 \\ \ddots & -0.0024 & -0.0007 \\ & +0.0003 & -0.0007 \\ & +0.0008 & +0.0009 \\ & +0.0017 & +0.0010 \\ & +0.0018 & +0.0011 \\ & +0.0021 & +0.0012 \\ & +0.0025 & +0.0013 \\ & +0.0042 & +0.0019 \\ \text { MEAN VALUE } & +0.0044 & \\ \text { AVERAGE DEVIATION } & +0.0006 & +0.0001 \\ \text { STANDARD DEVIATION } & +0.0025 & +0.0014 \\ & +0.0030 & +0.0016\end{array}$



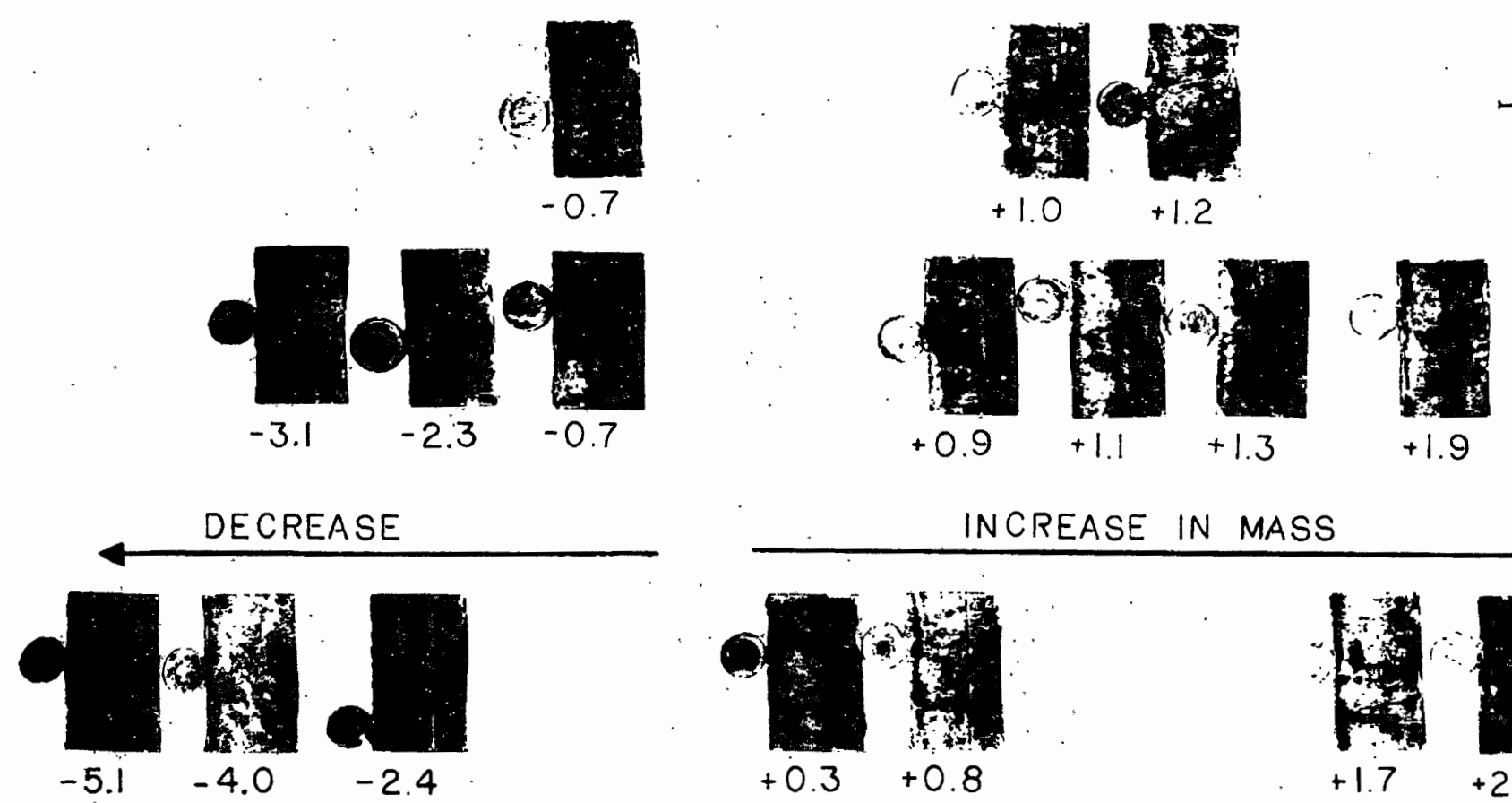

NCREASE IN MASS

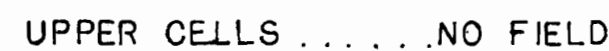

LOWER CELLS . . . . 4.5 KILOGAUSS.

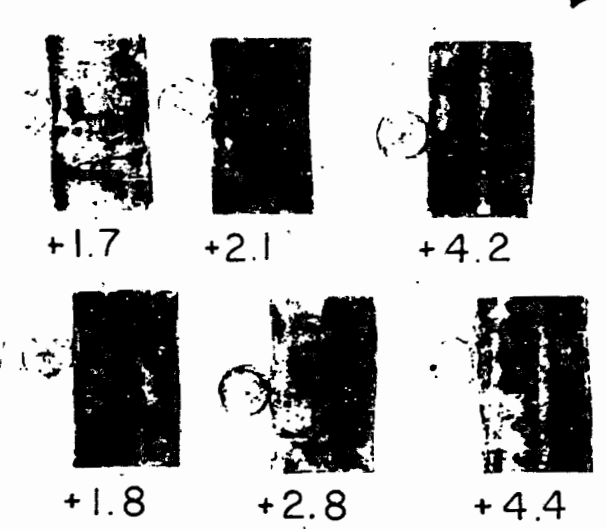

FIGURE 17. INTERIOR SURFACE OF ZINC CANS AT END

OF EXPERIMENT C. MASS CHANGE IS IN MILLIGRAMS. 
mass .

Exporiment D

This experiment is identical with Experiment $B$ except that none of the rectangular specimens wers allowed to corrode with a magnetic field applied at the bottom odge (see Figure 15). Data is given in rable VII.

\section{DISCUSSION OF RESULTS}

Exporimonts $A, B, C$, and $D$ rere performed by allowing zinc metal to corrode in an electrolytic solution. For Experiments A, B, and D, the mass of the specimens decreased, but the results are conflicting. In $A$ and $D$, the zinc specimens which were allowed to corrode in a magnetic field have a greater mass loss than the specimens corroding with no applied field. But in Experiment B, the specimens outside, the field have the greater mass loss.

Also, in Fxperiment $B$, there is a definite difference in mass loss between the two groups of zinc strips which were allowed to corrode with a magnetic field centered on different ends which were at different depths in the electrolyte. The strips with the field centered on the edge near the surface had the greater mass loss. Both of these groups did, however have a smaller mass loss than the thind group of $z$ inc strips which were allowed to corrode without the applied magnetic field.

So while the results indicate that the magnetic field reduces the corrosion of zinc in Experiment B, it does so to a greater extent when it acts further from the surface of the electrolyte. Differential aeration (see Figure 18) would cause the lower part of the zinc strip 
(which is a orated to a lesser degree) to corrode at a greater rate. It would then appear that the magnetic field inhibits the zinc oxidation reaction, having a lesser effect near the surface where the cathodic reaction dominates. However, this theory conflicts with Experiments A. and $D$, where the field appears to promote corrosion.

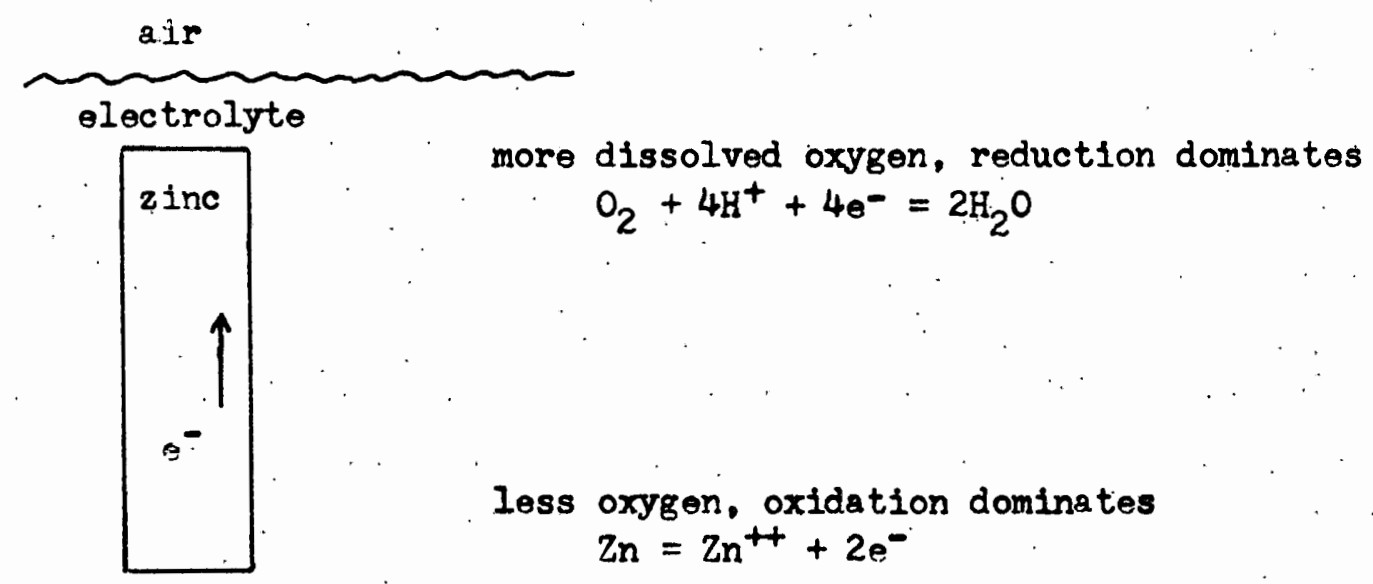

Figure 18. Schematic picture of differential aeration. The avallability of oxygen causes the upper part of the zinc strip to be cathodic with respect to the bottom.

In Experiment $C$, the corroding zinc cans actually gained mass, and it is assumed that zinc compounds (formed as the zinc oxidized) adhered to the metal. The cans that corroded within the applied field gained significantly more mess than the cans outside the field (see Table VIII). The standard deviation for the values of mass change of the individual cans in the fleld was almost twice that of the cans outside the field. No explanation was developed for this or for the change in width of the electrolyte-air line on the interior surface of the zinc cans. This liquid-air line could possibly be caused by dif- 
ferential aeration, although this has not been investigated (see

Figure 19).

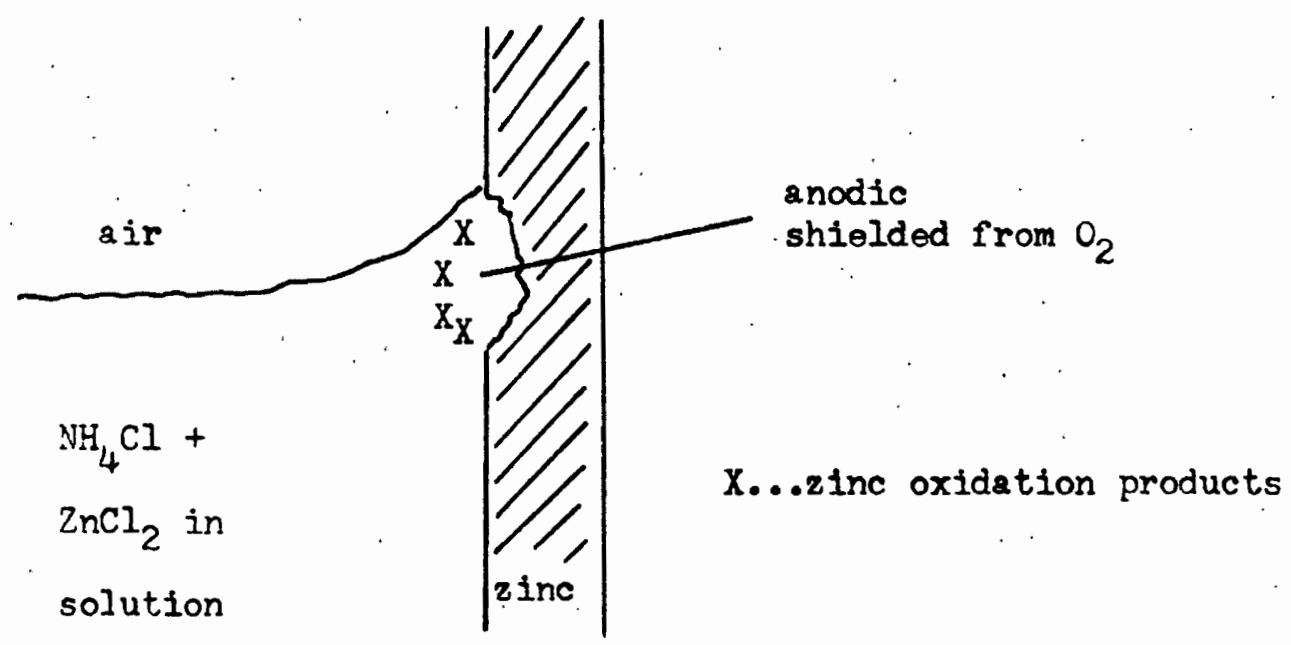

Figure 12. Possible explanation for the liquid-air line on the interior surface of the zinc cans used in Experiment $C$. Corrosion initiated at a weak point of the metal surface might lead to the formation, along the meniscus where the renewal of oxygen is easy. of a membrane of oxidized zinc products. This might then shield the zinc surface underneath from access of oxygen, making it anodic with respect to areas with aerated pessive regions. 
CONCLUSIONS

An applied magnetic field apparently can affect the energy output of a Ieclanché cell in two ways, depending on the strength of the field. Below $2 \mathrm{kG}$, the data suggests a decrease in energy output for the cells drained with an applied field (see Appendix F). This could be caused by an increase in cell impedance due to a Hall effect (page 3). At field strengths of $2.5 \mathrm{kG}$ or larger, an increase in energy output is indicated (Appendix F). No well-grounded explaination has yet been developed and more work is necessary. Possibly, for large enough field strengths, the decrease in mobility of $\mathrm{H}^{+}$would permit a more active role for a secondary charge carrier.

The original problem of magnetic effects at a solution-metal interface is still unsolved. More work must be done in this area. The action at the zinc-slectrolyte interface in the Leclanché cell was masked by the rate-determining step at the cathode. 


\section{REF ERENCES}

1 J. Dash and W. W. King, J. Electrochem. Soc.. 119, 51 (1972)

2 A. W. Adamson, A Textbook of Fhysical Chemistry, chapter 12, section 12-ST-1, Acedemic Press, 1973

3 D. Laforgue-Kantzer, Electrochimia Acta, 10, 585 (1965)

4 J. Tung, Unpublished research, 1972

5 R. T. Chen and K. Housen, Unpublished research, 1975

6 J. Davis, Dry Cell, Encyclopedia of Science and Technology, vol. 4, McGraw-Hill, 1971.

7 handbook of Chemistry and Physics. 51st odition (1970-1971), The Chemical Rubber Co.

8 S. Ghosh and J. P. Brenet, Electrochimica Acta, 2, 449 (1962)

9 D. B. Matthews, Rev. Pure and Appl. Chom., 20, 103 (1970)

10 A. B. Scott, J. Electrochem. Soc., 107, 941 (1960)

11 A. W. Adamson, A Textbook of Physical Chemistry, chapter 2, section 2-7, Acedemic Fress, 1973 


\section{APPENDIX A}

THE CALCULATION OF THE ENERGY OUTPUT AND THE A:MOUNT OF CHARGE PASSED BY A LECLANCHÉ CELL

The energy output of the Leclanché cells in the cell discharge experiments is given by

$$
E=\int P d t=\frac{1}{R} \int v^{2} d t=\frac{1}{R} \sum_{k=1}^{n} \int_{0}^{r} v_{k}^{2} d t
$$

where the voltage-time plot of the experiment has been divided into $n$ segments of width $\tau, R$ is the resistance load of the cell drainage experiments, $V_{k}$ is the voltege as a function of time for segment $k$, and $\tau$ is the width of the segment.

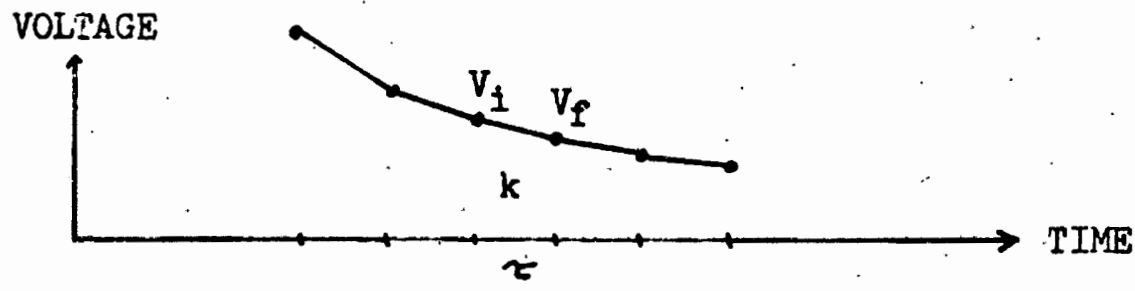

Figure 20. In the calculation of energy output and charge passed, the voltage of the cell sets as a function of time is assumed to be in Iinear segments. Segment $k$. is labelod.

If $V_{k}$ is assumed to be equal to a linear function for each segment and $v_{i}, v_{f}$, to be the initial and final voltages of those segments, then

$$
E=\frac{1}{R} \sum_{k=1}^{n} \int_{0}^{\tau} v_{k}^{2} d t \simeq \frac{1}{R} \sum_{\substack{211 \\ \text { segments }}} \int_{0}^{\tau}\left(v_{i}+\left(v_{f}-v_{i}\right) t / \tau\right)^{2} d t
$$


42

where...

$$
v_{k}=v_{1}+(\operatorname{slop} \theta)(t i m \theta)=v_{i}+\left(v_{f}-v_{i}\right) t / \tau
$$

Simple integration yields

$$
E=\frac{\tau}{3 R} \sum\left(V_{f}^{2}+v_{i} v_{f}+v_{1}^{2}\right)
$$

summed over all segments. The charge passed is given by

$$
\begin{aligned}
& Q=\frac{1}{R} \int V d t=\frac{1}{R} \sum_{k=1}^{n} \int_{0}^{r} v_{k} d t \\
& Q=\frac{\tau}{2 R} \sum\left(v_{1}+V_{f}\right)
\end{aligned}
$$

summed over all segments. 


\section{APPENDIX B}

\section{THE CALCULATION OF THE INERGY OUTPUT AND THE AMOUNT OF CHARGE PASSED IN EXPERIMENT 9}

In experiment 9, both sots of cells were wired in series with a common resistance load (s9e Figure 7). For this case, the energy out-. put for the set of cells without the field is given by

$$
\begin{gathered}
E_{A}=\int P d t=\int I V_{A} d t \\
E_{A}=\frac{1}{R} \int V_{R} V_{A} d t
\end{gathered}
$$

whore, at any time $t, V_{A}$ is the potential difference across the cells, $V_{R}$ is the voltage drop across $R$, and $I=V_{R} / R$ is the current.

As in Appendix A, the voltage-time plot has been divided into $\theta$ equal segments of width $\tau$, and for each segment, the voltage is assumed to be a linear function of time. Therefore, we have for $V_{A}$ and $V_{R}$.

$$
\begin{aligned}
& V_{R}=V_{R i}+\left(V_{R f}-v_{R i}\right) t / \tau \\
& V_{A}=v_{A i}+\left(V_{A f}-V_{A i}\right) t / \tau
\end{aligned}
$$

whore for oach segment, $V_{R I}$ and $V_{R f}$ are the initial and final voltages of the resistance losd, and, $V_{A 1}$ and $V_{A f}$ aro the initial and final potential differences of the cells drained without an applied magnetic field.

The energy output is then given by

$$
E_{A}=\frac{\tau}{6 R} \sum\left(2 V_{R i} V_{A i}+V_{R i} V_{A f}+V_{R f} V_{A I}+2 V_{R f} V_{A f}\right)
$$


whore the summation is over all segments.

The expression for the charge passed by the same set of cells is given by

$$
\begin{aligned}
& Q_{A}=\int I d t=\frac{1}{R} \int V_{R} d t \\
& Q_{A}=\frac{\tau}{2 R} \sum\left(V_{R i}+V_{R f}\right)
\end{aligned}
$$

whare tho summation is over all segments.

The equations for the energy output and charge passed for the cells drained in an applied magnetic field are identical. 


\section{APPENDIX C}

\section{MAGNETS USED IN EXPERIMENTS}

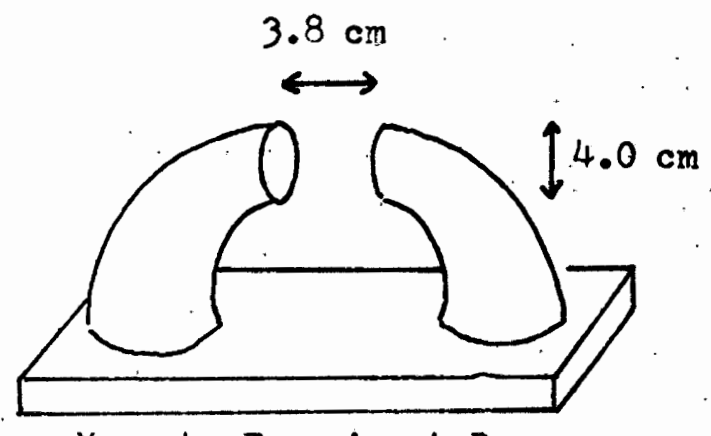

Niagnet, Experiment $D$

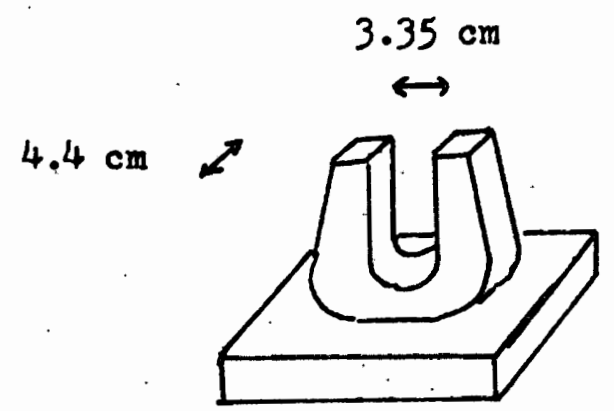

Magnet II

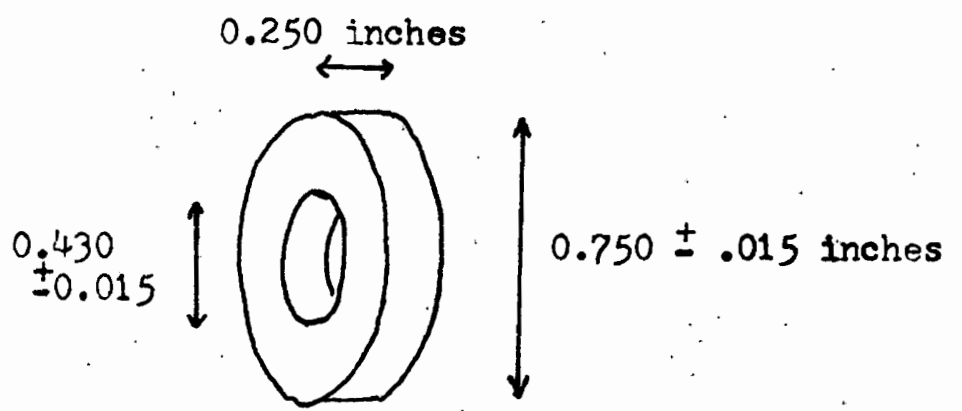

Nagnet III. IV

Edmund Scientific \#30,730 


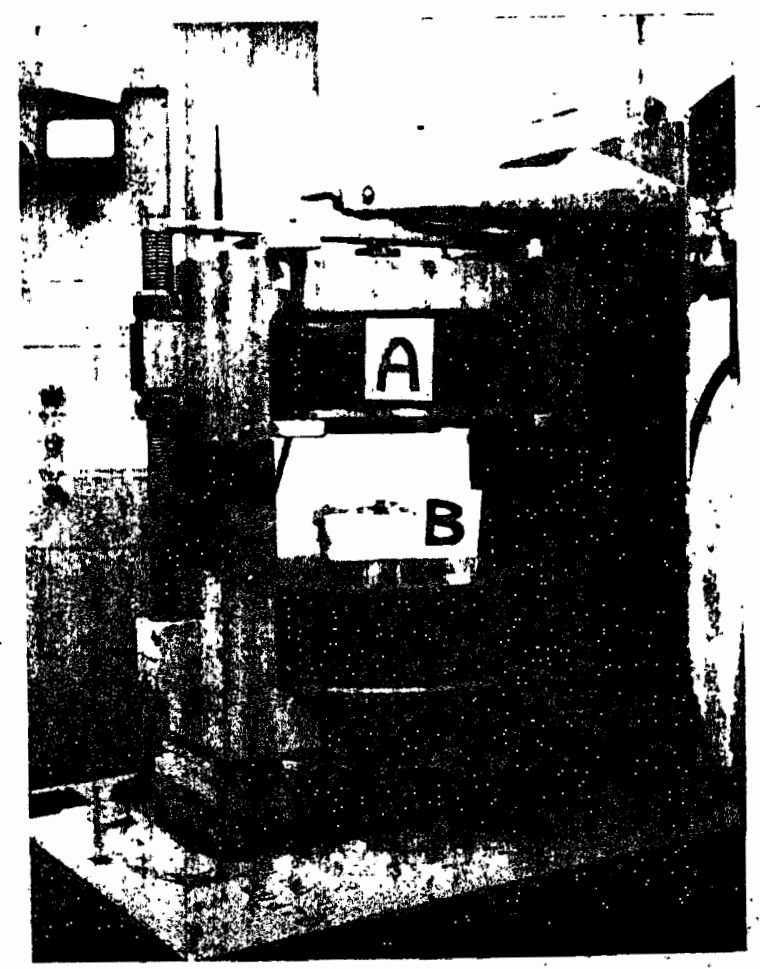

Kagnet I

A...Varian model V-4007 electromagnet, with the pole pleces (six inch diameter) turned to provide a vertical magnetic field

B...Polystyrene container in which the cells were placed, along with a mixture of water and ice to maintain constant temperature 


\section{APPENDIX D}

INTTIAL CALCULATIONS OF ENFRGY OUTPUT AND CHARGE PASSED FOR T IF FIRST 100 MINUTES OF EXPERIMENTS 5, 6, 7, 8, AND 9

\section{Exporiment 5}

\begin{tabular}{|c|c|c|c|c|}
\hline \multirow[t]{2}{*}{$\begin{array}{c}\text { TIME } \\
\text { (minutes) }\end{array}$} & \multicolumn{2}{|c|}{$\begin{array}{l}\text { ENERGY OUTPUT } \\
\text { (joules) }\end{array}$} & \multicolumn{2}{|c|}{$\begin{array}{l}\text { CHARGE. PASSED } \\
\text { (coulombs) }\end{array}$} \\
\hline & FIEI D & NO FIELD & FIELD & NO FIELD \\
\hline $\begin{array}{r}0 \\
1 \\
2 \\
3 \\
4 \\
5 \\
6 \\
7 \\
8 . \\
9 \\
10\end{array}$ & $\begin{array}{c}0 \\
407 \\
756 \\
1080 \\
1390 \\
1690 \\
1970 \\
2250 \\
2520 \\
2790 \\
3040\end{array}$ & $\begin{array}{r}0 \\
270 \\
508 \\
730 \\
939 \\
1140 \\
1330 \\
1520 \\
1700 \\
1876 \\
2050\end{array}$ & $\begin{array}{c}0 \\
72.8 \\
140 \\
205 \\
269 \\
331 . \\
392 \\
452 \\
512 \\
571 \\
629\end{array}$ & $\begin{array}{c}0 \\
59.7 \\
115 \\
169 \\
221 \\
272 \\
322 \\
372 \\
420 \\
468 \\
516\end{array}$ \\
\hline 20 & 5350 & 3600 & 1180 & 965 \\
\hline 30 & 7160 & 4860 & 1660 & 1370 \\
\hline 40 & 8570 & 5870 & 2090 & 1730 \\
\hline 50 & 9700 & 6700 & 2480 & 2060 \\
\hline 60 & 10700 & 7420 & 2830 & 2370 \\
\hline 70 & 11600 & 8060 & 3170 & 2660 \\
\hline 80 & 12400 & 8620 & 3500 & 2930. \\
\hline 90 & 13100 & 9130 & 3800 & 3190 \\
\hline 100 & 13800 & 9590 & 3970 & 3430 \\
\hline
\end{tabular}


axperiment 6

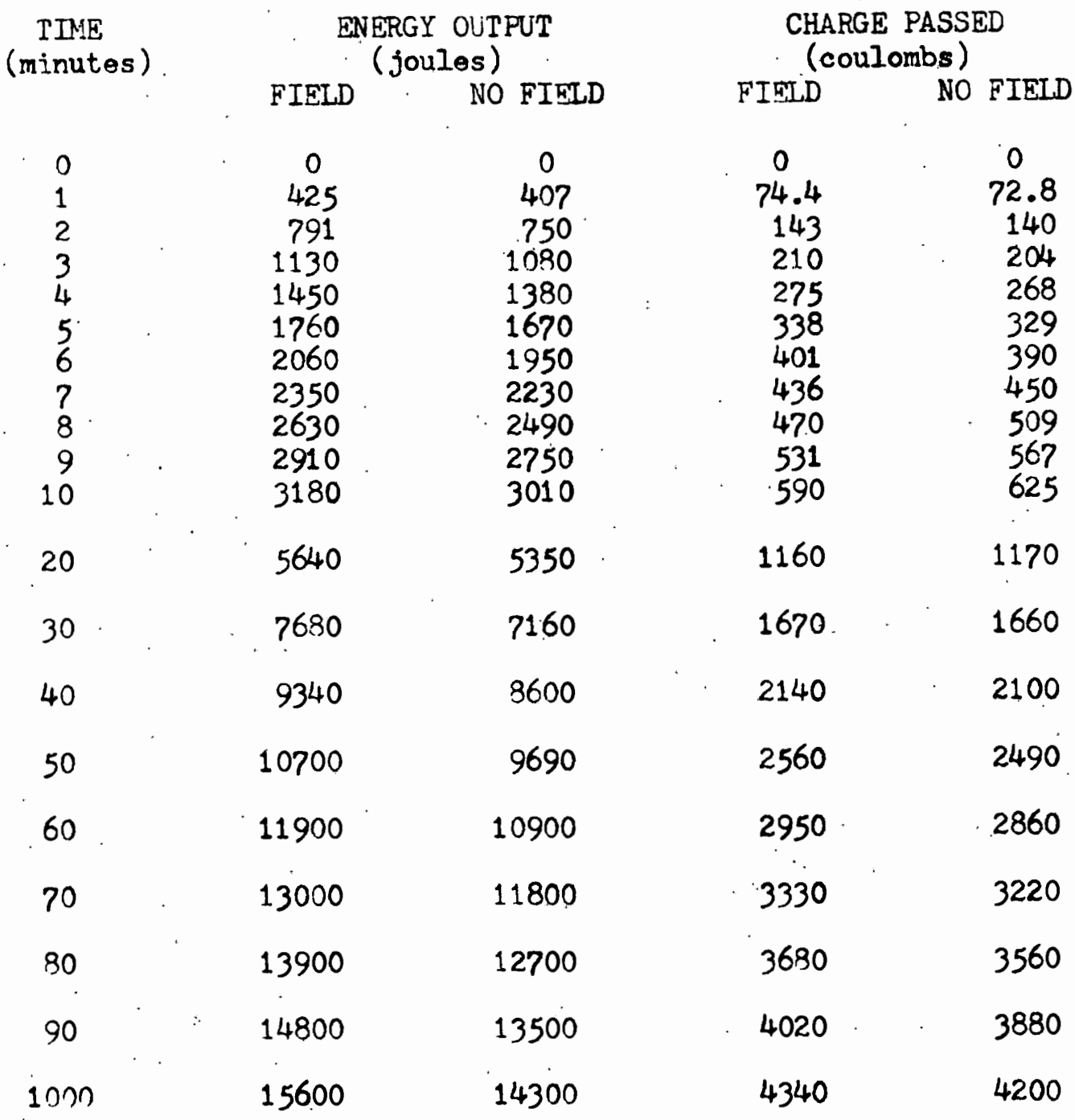


Experiment ?

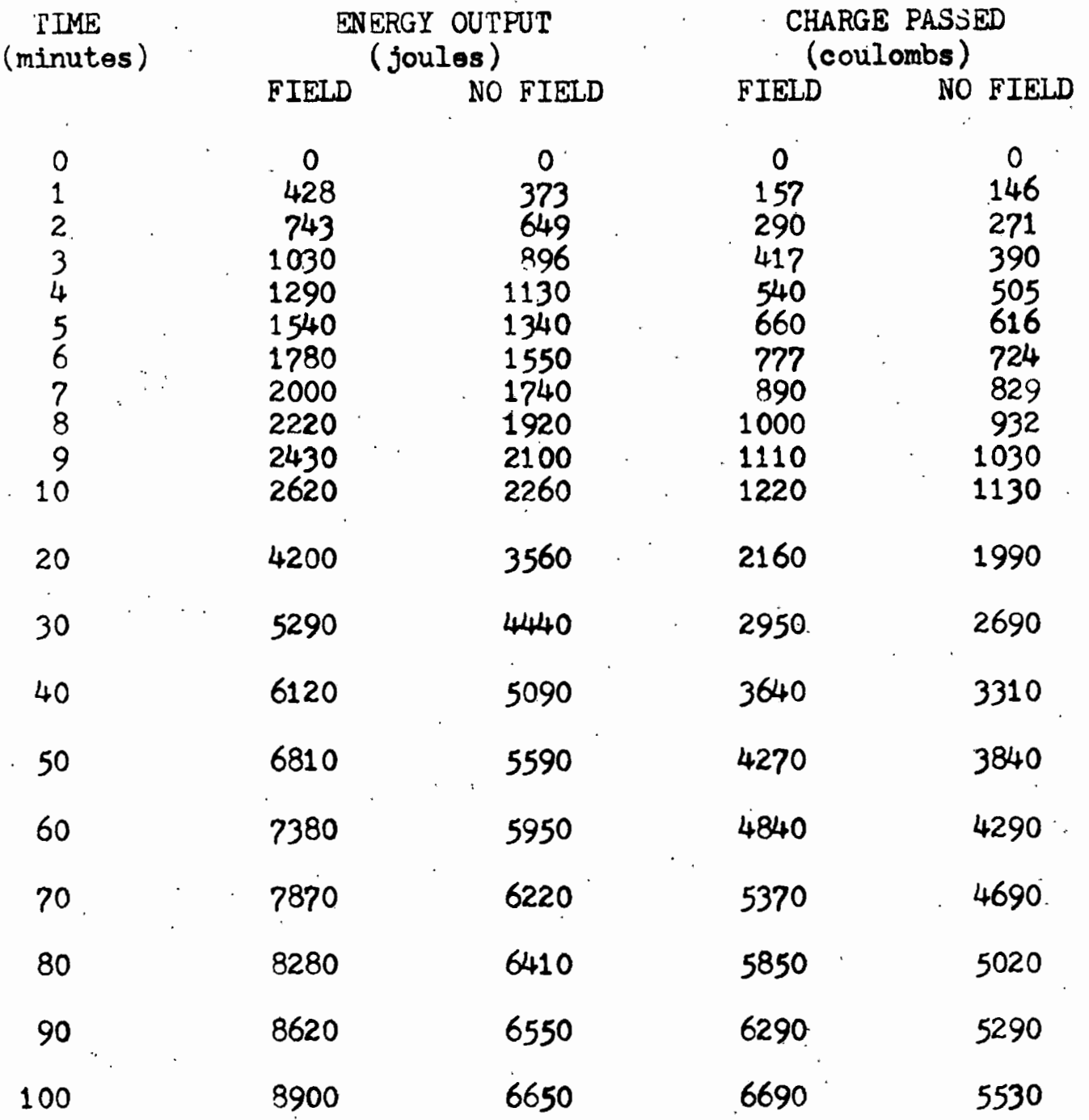


Experiment 8

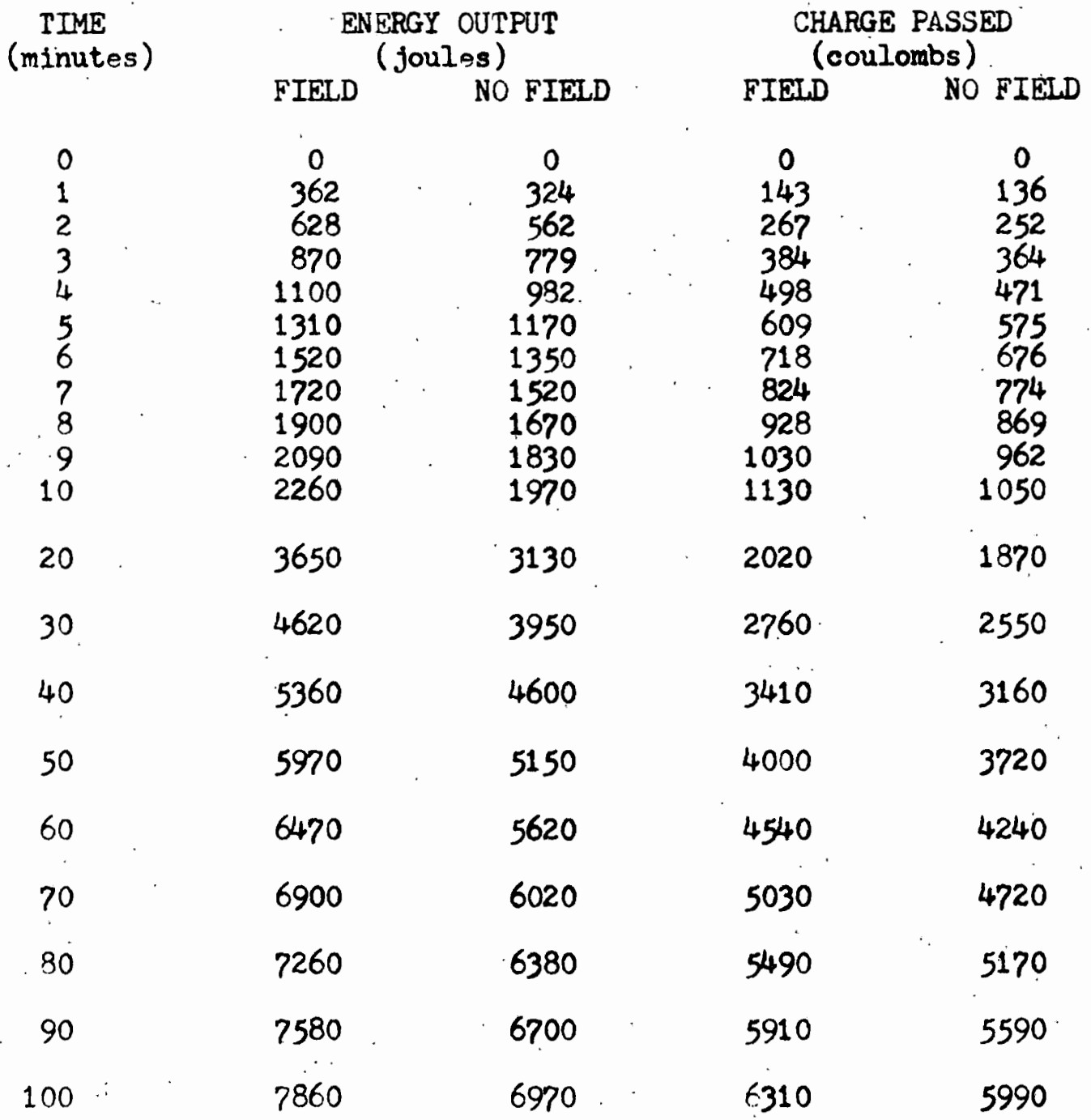


Experiment 9

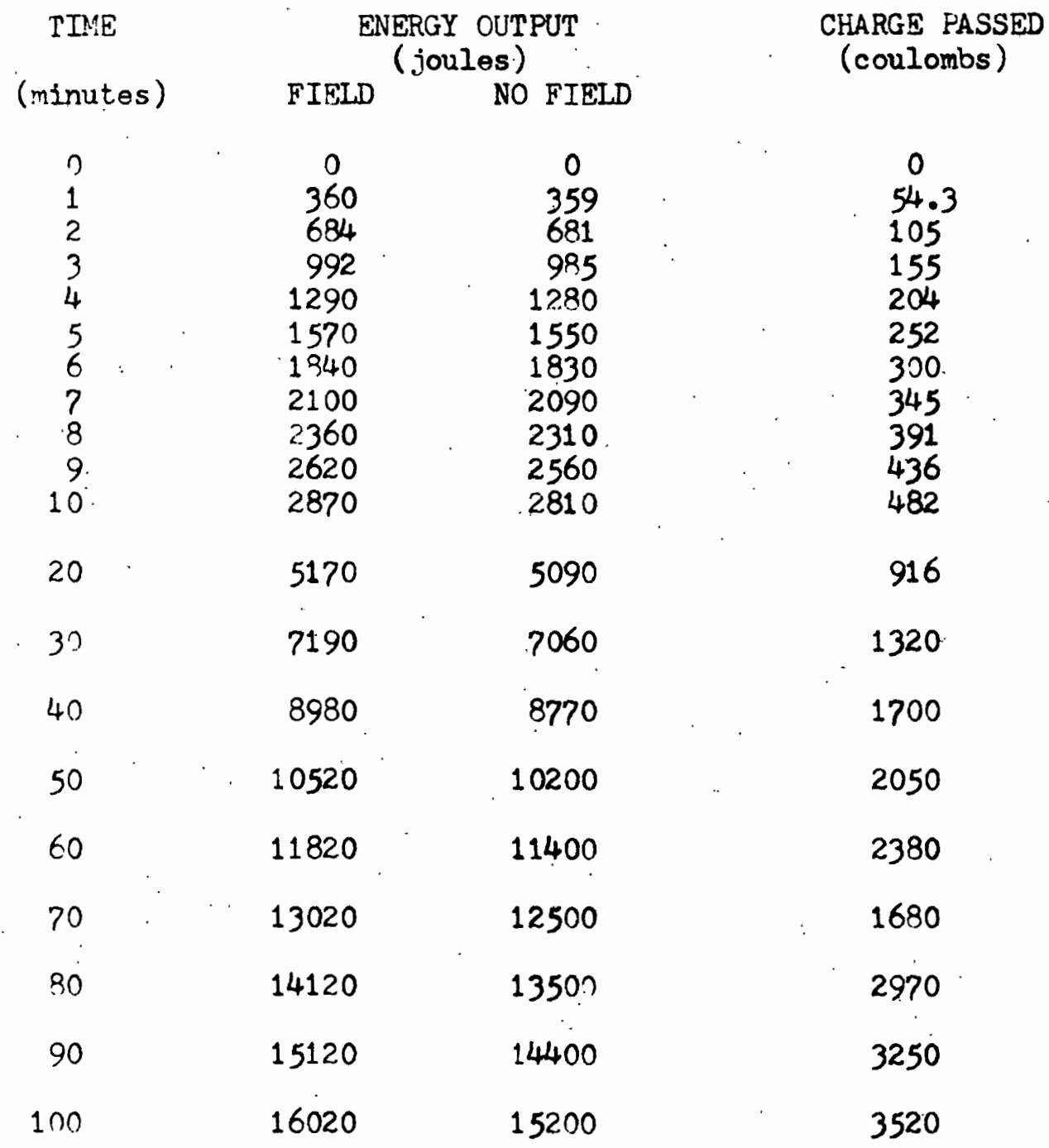




\section{APPENDIX E}

\section{ERROR ANALYSIS}

Error in the calculation of the energy passed and in the amount of charge passed by the Leclanché cells in Experiments 1 through 26 may arise from 3 sources:

1. The value of the resistance load of the cells

2. The accuracy of the strip chart recorder in recording voltage and time passad

3. The substitution of a summation for an integral in the calculation of the energy output and of the amount of charge passed.

The resistance loads were known to within $1 \%$ except for experiments 7 and 8 , where the values were given to $2 \%$.

The strip chart recorder used (Houston Instruments Omnigraphic $2-3000$ ) was accurate to $\pm 0.2 \%$ for the voltage (full scale) and $\pm 0.1 \%$ for the time.

The estimation of the extent of error due to the substitution of a summation for an integration: (equations 8 and 9) was not straghtforward. The summations were usually taken over time intervals of 10 minutes. To illustrite the possible inaccuracy, sample calculations were made of energy output for the cells drained without an applied magnotic field in Experiment 7. This experiment was choosen because it has a large initial voltage drop in the first few minutes of the experimant due to a low resistance load ( 1.05 ohms $\pm 2 \%$ ). The energy output was calculated for the first 100 minutes according to equation 8 , 


$$
E=\frac{\tau}{3 R} \sum\left(v_{f}^{2}+v_{i} v_{f}+v_{i}^{2}\right)
$$

where $\tau$ is the size of the time interval. A comparison was made between the values obtained with $\tau=10$ minutes and $\tau=1$ minute. This will provide a rough estimate of the expected error in using a summation over intarvals of 10 minutes instead of integration (the limit as $\tau \rightarrow$ 0 ) in equation 8. Values of energy output were calculated for $10 \mathrm{mi}$ nute portions of the experiment.

$\begin{array}{lccc}\begin{array}{c}\text { Portion of } \\ \text { Experiment }\end{array} & \text { minutes } & \text { minute } & \begin{array}{c}\text { Porcentage } \\ \text { Difference }\end{array} \\ \begin{array}{c}\text { first } 10 \text { minute } \\ \text { portion }\end{array} & 2970 & 2280 & 30 \% \\ \text { second } & 1300 & 1390 & 6.5 \% \\ \text { third } & 973 & 970 & 1.0 \% \\ \text { fourth } & 655 & 651 & 0.6 \% \\ \text { firth } & 447 & 449 & 0.5 \% \\ \text { sixth } & 370 & 370 & - \\ \text { seventh } & 268 & 268 & - \\ \text { eighth } & 193 & 191 & 1.0 \% \\ \text { ninth } & 135 & 133 & 1.5 \% \\ \text { tenth } & 99 & 98 & -\end{array}$

3xcept for the first 10 minutes of the experiment, the difference between the values for the energy using $\tau=1$ minute and $\tau=10 \mathrm{ml}$ nutes is liss than 18 over the entire experiment. Because of the large difference in the first few minutes, experiments using low resistances loads (around 1 ohm) had the energy output and charge passed for the 
first 10 minutes calculated with $\tau=1$ minute. The error involved in calculating the charge passed is much less since it is proportional to only the first power of the voltage (see equation 9). All experimental calculations are therefore rated at $1 \%$.

The magnitudes given for the fleld strengths used are accurate to a tenth of a kilogauss except for the ring magnets (III and IV in Table I). The field strengths for these last vary greatly but are approximately one kilogauss at their centers, increasing to about 2 kilogauss next to the inner surface of the magnets.

The temperature given for cells drained in an ice-water bath is $0^{\circ} \mathrm{C}$ and any variation due to atmospheric pressure or Joule heating is considered minimel. Experiments performed at room temperature are listed as $22^{\circ} \mathrm{C}$ and may vary within a degree. However, in all cases. the axperiments were performed in pairs with one group of cells drained in a magnetic field and with the second group drained in an identical manner but without the applied magnetic field. 


\section{APPENDIX F}

\section{STATISTICAI ANAIYSIS}

In Talbe I are listed the results of 26 experiments. The experimental conditions of these, however, are widely varied.

In order to investigate the reproducibility of these results, those experiments performed under similar conditions were arranged in groups. The mean and standard deviations of the energy outputs of these similar experiments were then calculated.

Group 1 (as given in Table I)

$\begin{array}{ccc}\text { Experiment No. } & \text { Field (kG) } & \text { Energy (joules) } \\ 2 & 4.5 & 12,900 \\ & 0 & 12,000 \\ 3 & 4.5 & 10,400 \\ & 0 & 11,500 \\ 4 & 4.5 & 12,000 \\ & 0 & 11,600 \\ \text { With field: } & \text { mean } E=11,770 \text { joules } \\ & \text { standard deviation } \sigma=1,270 \\ \text { Without field: } & \text { mean E }=11,700 \text { joules } \\ & \text { standard deviation } \sigma=265\end{array}$


Group 2 (data recalculated for only the initial 100 minutes)

Experiment No.

10

11

12

13
Field ( $k G)$

1.5

0

1.5

0

1.0

0

1.0

0
Energy (joules)

1,240

1,110

1,130

1,320

1.430

1,520

1,110

1,120

With field: mean $E=1,230$ joules

standard deviation $\sigma=147$

Without field: mean $E=1,270$ joules

$$
\text { standard deviation } \sigma=194
$$

Group 3 (as given in Table I)

Experiment No.

17

18

19
Field (kG) Energy (joules)

1.1

0

1.1
0

1.1
0
4,750

4.630

4,620

4,700

4.790

4,860

With field: mean $E=4,720$

standard deviation $\sigma=89$

Without field: mean $E=4,730$

standard deviation $\sigma=118$ 
Group 4 (as given in Table I)

$\begin{array}{ccc}\text { Experiment No. } & \text { Field }(k G) & \text { Energy (joules) } \\ 20 & 2.5 & 2,370 \\ & 0 & 2,340 \\ 21 & 2.5 & 2,400 \\ & 0 & 2,370 \\ 22 & 2.5 & 2,450 \\ & 0 & 2,310\end{array}$
With field: mean $E=2,410$ joules
standard deviation $\sigma=40$
Without field: mean $E=2,340$ joules
standard deviation $\sigma=30$

Group 5 (as given in Table I)

$\begin{array}{ccc}\text { Experiment No. } & \text { Field }(k G) & \text { Energy (joules) } \\ 24 & 2.5 & 2,990 \\ & 0 & 2,860 \\ 25 & 2.5 & 2,860 \\ & 0 & 2,880 \\ 26 & 2.5 & 2,990 \\ & 0 & 2,870\end{array}$

$\begin{array}{ll}\text { With field: } & \begin{array}{l}\text { mean } E=2,925 \text { joules } \\ \text { standard deviation } \sigma=92\end{array} \\ \text { Without field: } & \begin{array}{l}\text { mean } E=2,870 \text { joules } \\ \text { standard deviation } \sigma=10\end{array}\end{array}$

In all the above groups, the mean values have deviations that overlap. This is interpreted as a result of the variability of the individual cells. However, the datz still strongly suggests an influence of the energy output due to the presence of an applied magnetic field. This is more clearly seen by considering those experiments in which the field used is less than $2 \mathrm{kG}$. For these experiments, $70 \%$ 
(7 out of 10) show a negative effect on the energy output. For the experiments with $B \geqslant 2.5 \mathrm{kG}, 75, \mathrm{f}$ (12 out of 16 ) show a increase in energy output.

\section{EXPERIMENTS PERFORMED NITH $\mathrm{B}<2.5 \mathrm{kG}$ \\ (from Table I, page 12)}

$\begin{array}{ccc}\text { Experiment No. } & \begin{array}{c}\text { Number of cells } \\ \text { in each set }\end{array} & \begin{array}{c}\text { Percentage increase in } \\ \text { energy output }\end{array} \\ 10 & 3 & -0.6 \% \\ 11 & 3 & -5.5 \% \\ 12 & 3 & -2.2 \% \\ 13 & 3 & -3.9 \% \\ 14 & 2 & +0.6 \% \\ 15 & 3 & -11 \% \\ 16 & 6 & +7.4 \% \\ 17 & 6 & +2.6 \% \\ 18 & 6 & -1.7 \% \\ 19 & 6 & -1.4 \%\end{array}$


EXPFRIMENTS PERFORMED NITH $B \geqslant 2.5 \mathrm{kG}$

(from Table I, page 12)

\begin{tabular}{|c|c|c|}
\hline Experiment No. & $\begin{array}{l}\text { Number of cells } \\
\text { in each set }\end{array}$ & $\begin{array}{c}\text { Percentage increase in } \\
\text { energy output }\end{array}$ \\
\hline 1 & 6 & $+12 \%$ \\
\hline 2 & 1 & $+7.4 \%$ \\
\hline 3 & 1 & -9.68 \\
\hline 4 & 1 & $+3.4 \%$ \\
\hline 5 & 6 & $-0.3 \%$ \\
\hline 6 & 6 & $+27 \%$ \\
\hline 7 & 6 & $+46 \%$ \\
\hline 8 & 6 & $+24 \%$ \\
\hline 9 & 6 & $+47 \%$ \\
\hline 20 & 3 & $+1.3 \%$ \\
\hline 21 & 3 & +1.37 \\
\hline 22 & 3 & +6.18 \\
\hline 23 & 3 & $-1.4 \%$ \\
\hline 24 & 3 & $+4.5 \%$ \\
\hline 25 & 3 & $-0.7 \%$ \\
\hline 26 & 3 & $+4.2 \%$ \\
\hline
\end{tabular}

